\title{
O gênero Adiantum (Pteridaceae) no estado do Rio de Janeiro, Brasil ${ }^{1}$
}

\author{
The genus Adiantum (Pteridaceae) from Rio de Janeiro State, Brazil
}

\author{
Sara Lopes de Sousa Winter ${ }^{2}$, Lana da Silva Sylvestre ${ }^{3}$ \& Jefferson Prado ${ }^{4}$
}

\begin{abstract}
Resumo
Adiantum L. é um gênero facilmente reconhecível pela presença de pseudo-indúsio com nervuras, formado pela margem revoluta da lâmina. Compreende espécies terrestres ou epipétricas. É um grupo Pantropical com cerca de 200 espécies, sendo que 70 delas ocorrem na América do Sul e 62 no Brasil. Adiantum ocorre principalmente no interior de florestas primárias e secundárias, desde o nível do mar até cerca de 2.000 metros de altitude. Visando-se o conhecimento regional do grupo no Brasil, o presente trabalho apresenta o levantamento do gênero Adiantum no estado do Rio de Janeiro, fornecendo chave de identificação, descrições, comentários e ilustrações das espécies. Existem 20 espécies de Adiantum no Estado, correspondendo a 30\% do número total registrado para o Brasil e podem ser encontradas desde florestas úmidas até restingas, desde o nível do mar até 850 metros de altitude. Dentre as espécies inventariadas, algumas possuem ampla distribuição na América Central e América do Sul (70\%), enquanto outras são endêmicas do Brasil (30\%).
\end{abstract}

Palavras-chave: Adiantoideae, Floresta Atlântica, samambaias, taxonomia.

\begin{abstract}
The genus Adiantum L. can be easily recognized by the pseudoindusium formed by the revolute margin of the lamina and with veins. The species of this genus are terrestrial or lithophytics. It is a Pantropical group with approximately 200 species, 70 of which occur in South America, and 62 in Brazil. Its species are usually found in primary and secondary forests, from sea level to 2,000 meters. Aimed the regional knowledge of this group in Brazil, this study reports a floristic survey of the genus Adiantum to the state of Rio de Janeiro, providing an identification key, descriptions, comments, and illustrations of the species. There are 20 species of Adiantum in the state, corresponding to $30 \%$ of the species recorded to Brazil. They can be found in rainforests and sandy coastal plain vegetation, from sea level to 850 meters. Some species have a wide range of distribution in Central and South America (70\%), whereas others are endemic to Brazil (30\%).
\end{abstract}

Key words: Adiantoideae, Atlantic Forest, ferns, taxonomy.

\section{Introdução}

Com cerca de 50 gêneros e mais de 1.000 espécies, o que corresponde a $10 \%$ das samambaias leptosporangiadas atuais (Schuettpelz et al. 2007), Pteridaceae é amplamente distribuída pelo mundo, especialmente nos Trópicos, onde 11 gêneros são restritos ao Novo Mundo e nove ao Velho Mundo (Prado et al. 2007). Ocorre em diversos tipos de ambientes e isto a difere das outras famílias de samambaias, apresentando espécies herbáceas terrestres, epipétricas ou epífitas, adaptadas desde ambientes aquáticos a xéricos (Schuettpelz et al. 2007).

Pteridaceae constitui um grupo monofilético com alto grau de suporte. Compreende cinco grupos também monofiléticos (Smith et al. 2006; Schuettpelz et al. 2007; Prado et al. 2007), sendo um deles representado pela sub-família Adiantoideae, a qual compreende o gênero Adiantum e as espécies anteriormente incluídas em

\footnotetext{
${ }^{1}$ Dissertação de Mestrado da primeira autora. Programa de Pós-graduação em Botânica do Museu Nacional, UFRJ.

${ }^{2}$ Museu Nacional, Universidade Federal do Rio de Janeiro. Quinta da Boa Vista s.n. São Cristóvão, Rio de Janeiro, RJ. 20940-040. Autor para correspondência: swpteridos@yahoo.com.br

${ }^{3}$ Universidade Federal do Rio de Janeiro, Instituto de Biologia, Depto. Botânica. R. Prof. Rodolpho P. Rocco 211, CCS, Bloco A, 21941-902, Rio de Janeiro, RJ.

${ }^{4}$ Instituto de Botânica de São Paulo, Herbário. C.P. 3005. São Paulo, SP. 01031-970.
} 
Vittariaceae (sensu Kramer 1990), formando um clado bem suportado, com ca. de 12 gêneros e 300 espécies (Schuettpelz et al. 2007).

Adiantum é um gênero Pantropical, com cerca de 200 espécies distribuídas nos trópicos de ambos os hemisférios, ocorrendo em florestas primárias e secundárias, em altitudes que variam desde o nível do mar até 5.000 metros nos Andes (Prado et al. 2007). Cerca de 70 espécies ocorrem na América do Sul (Lellinger \& Prado 2001), das quais 62 estão representadas no Brasil (Prado 2010). Segundo Prado (2000), no País este gênero ocorre principalmente em florestas primárias e secundárias, desde o nível do mar até cerca de 2.000 metros de altitude.

O gênero Adiantum é parafilético, mas pode se tornar monofilético se as espécies $A$. raddianum e A. cuneatum, que formam um clado bem suportado, forem segregadas para outros táxons (Prado et al. 2007). As espécies A. serratodentatum, A. obliquum, A. latifolium e A. terminatum formam um clado bem definido e com alto grau de suporte, que possivelmente poderão caracterizar um subgênero (Prado et al. 2007).

As espécies de Adiantum que ocorrem no estado do Rio de Janeiro estão inseridas em uma das regiões de mais alta diversidade e um dos principais centros primários de endemismos da Região Neotropical para samambaias (Tryon 1972). Neste contexto, o presente trabalho tem como objetivo o levantamento das espécies do gênero Adiantum no estado do Rio de Janeiro, fornecendo chave, descrições e ilustrações que permitam a identificação das mesmas, indicando as áreas de maior riqueza e seus ambientes preferenciais no Estado.

\section{Material e Métodos}

O presente estudo foi baseado na análise de cerca de 480 espécimes provenientes de coletas dos autores e de materiais depositados em herbários brasileiros (GUA, HB, R, RB, RBR, RFA, RFFP, RUSU, SP). Os materiais selecionados encontram-se relacionados no tratamento taxonômico. Os acrônimos foram citados conforme Thiers (2010).

O trabalho de campo foi realizado de março de 2006 a março de 2007, visando a observação das populações no campo e a coleta de materiais adicionais para este estudo. O material coletado foi incorporado aos herbários R, RBR e SP.

A circunscrição dos táxons foi feita com base em todo material estudado, nas obras originais e na análise das fotos dos tipos e nos materiais- tipo, quando possível. As descrições dos táxons foram baseadas nos materiais procedentes do Rio de Janeiro, havendo a complementação de dados, sempre que necessário, pela análise de espécimes de outros estados (material adicional examinado) e por informações de campo. Os dados morfológicos utilizados nas descrições foram baseados na análise de, pelo menos, três espécimes de cada espécie.

A terminologia morfológica seguiu Lellinger (2002), com algumas modificações. A abreviatura dos nomes dos autores das espécies seguiu Pichi-Sermolli (1996).

A distribuição geográfica baseou-se em informações contidas na literatura específica para o grupo (Scamman 1960; Tryon \& Stolze 1989; Mickel \& Smith 2004) e em alguns levantamentos florísticos realizados no Brasil (Prado \& PalaciosRios 1998; Prado 2003, 2004, 2005a, b; Winter et al. 2007; Boldrin \& Prado 2007), complementados pela análise de coleções depositadas em herbários.

Para a caracterização da vegetação foi adotado o sistema de Veloso et al. (1991) e os comentários referentes aos substratos e ambientes preferenciais basearam-se na observação do material no campo.

Por fim, atenta-se que as espécies exóticas de Adiantum e as que são encontradas no estado do Rio de Janeiro como plantas cultivadas não foram incluídas neste estudo.

\section{Resultados e Discussão}

Vinte espécies de Adiantum foram registradas para o estado do Rio de Janeiro, correspondendo a $30 \%$ da diversidade deste gênero no Brasil. As espécies podem ser encontradas desde florestas úmidas até restingas, desde o nível do mar até 850 metros de altitude. São, em geral, amplamente distribuídas nas diversas fácies da floresta ombrófila densa no Estado, com predomínio das faixas altitudinais menos elevadas (florestas de terras baixas e submontanas). Dentre as espécies inventariadas, $70 \%$ possuem ampla distribuição na América Central e América do Sul e 30\% são endêmicas ao Brasil.

\section{Pteridaceae}

Plantas terrestres, epipétricas ou epífitas. Caule curto a longo-reptante, ascendente, subereto a ereto, provido de escamas ou tricomas. Frondes monomorfas, dimorfas ou hemidimorfas; pecíolo contínuo ao caule, com 1, 3 ou mais feixes vasculares na base; lâmina inteira, geralmente pinada, decomposta, pedada, radiada, palmada, helicoidal, glabra, com tricomas e/ou 
escamas, ou com indumento farináceo; nervuras livres e furcadas ou anastomosadas formando um padrão reticulado sem as vênulas inclusas nas aréolas. Soro marginal ou inframarginal, com indúsio freqüentemente formado pela margem revoluta do segmento (pseudo-indúsio), com ou sem nervuras, ou soros sem indúsio ao longo das nervuras, acrosticóides, recobrindo inteiramente a face abaxial da lâmina ou em sulcos lineares, com ou sem paráfises; esporângios globosos, numerosos, cada esporângio com um ânulo vertical interrompido pelo pedicelo, este com três fileiras de células; esporos triletes ou monoletes, tetraédrico-globosos, globosos ou reniformes, com várias formas de ornamentação, sem clorofila (Prado 2004; Smith et al. 2006).

\section{Adiantum L.}

Plantas terrestres ou epipétricas. Caule curto a longo-reptante ou subereto, com escamas.
Frondes monomorfas, cespitosas ou fasciculadas, eretas a patentes; pecíolo contínuo ao caule, castanho a púrpuro, lustroso, glabro a densamente coberto por escamas ou tricomas; lâmina 1-5-pinada, deltóide a helicoidal; segmentos dimidiados a trapeziformes, lanceolados, flabelados, romboidais, sésseis ou curtamente peciolulados, articulados ou não, glabros ou com tricomas na lâmina, com ou sem idioblastos; venação livre, nervuras simples ou furcadas, ou areoladas; soros marginais, sem paráfises, curtos, oblongos, reniformes ou lineares, um a muitos por segmento, recobertos por um falso indúsio formado pela margem revoluta da lâmina (pseudo-indúsio), com nervuras, glabro ou pubescente; esporângios formados sobre as margens recurvadas e modificadas da lâmina; esporos tetraédricoglobosos (Prado 2004).

\section{Chave para identificação das espécies de Adiantum no estado do Rio de Janeiro}

1. Lâmina 1-pinada.

2. Raque prolífera no ápice, pinas articuladas à raque

3. A. deflectens

2'. Raque não prolífera no ápice, pinas não articuladas.

3. Raque e pinas glabras; pinas oval-deltóides

8. A. macrophyllum

3'. Raque e pinas pubescentes; pinas lanceoladas .

4. Nervuras livres; vários soros por pina; indúsio glabro; raque com tricomas e escamas linear-lanceoladas com base pectinada; cor do peciólulo passando para a base da pina

10. A. obliquum

4'. Nervuras irregularmente anastomosadas; dois soros por pina, indúsio com tricomas; raque somente com escamas lanceoladas de base pectinada; cor do peciólulo interrompida na base da pina

4. A. dolosum

1'. Lâmina 2-pinada ou mais dividida.

5. Lâmina 2-pinada.

6. Raque glabros; pínulas articuladas, cor do peciólulo interrompida na base da pínula

5. A. glaucescens

6'. Raque pubescentes; pínulas não articuladas, cor do peciólulo passando para a base da pínula

7. Raque com escamas lanceoladas, ocasionalmente com escamas filiformes ou tricomas; escamas aracnóides ausentes .

8. Raque com escamas lanceoladas e tricomas; indúsio glabro

10. A. obliquum

8'. Raque com escamas lanceoladas e/ou escamas filiformes; indúsio com tricomas

9. Raque somente com escamas lanceoladas; pínula abaxialmente densamente coberta por tricomas septados 18. A. terminatum

9'. Raque com escamas lanceoladas e escamas filiformes; pínula abaxialmente com escamas filiformes e tricomas articulados

19. A. tetraphyllum

7'. Raque com escamas lanceoladas a linear-lanceoladas; escamas aracnóides presentes

10. Indúsio com tricomas 14. A. pulverulentum

10’. Indúsio glabro.

11. Pínulas glabras abaxialmente 6. A. latifolium

11'. Pínulas pubescentes abaxialmente. 
12. Pínulas com 1-2 soros lineares, falcados

12'. Pínulas com 2 ou mais soros oblongos.

13. Pínulas abaxialmente com tricomas septados; 1-3 pares de pinas laterais ....20. A. windischii

13'. Pínulas abaxialmente com escamas linear-lanceoladas, base pectinada e escamas aracnóides; 4-11 pares de pinas laterais 16. A. serratodentatum

5'. Lâmina 3-pinada ou mais dividida.

14. Pínulas lanceoladas ou flabeladas.

15. Pínulas lanceoladas.

16. Raque, raquíola e pínulas com escamas e tricomas

12. A. papillosum

16'. Raque, raquíola e pínulas glabras

17. A. subcordatum

15'. Pínulas obovais a flabeladas.

17. Últimos segmentos com incisões chegando a $1 / 2$ da pínula, formando lobos arredondados 15. A. raddianum

17'. Últimos segmentos com incisões chegando a $2 / 3$ da pínula, formando lobos lineares .. 7. A. lorentzii

14'. Pínulas quadrangulares, trapeziformes ou deltóides.

18. Pecíolo e raque glabros distalmente.

19. Pínula quadrangular a trapeziforme, peciólulo $0,1-0,25 \mathrm{~mm}$ compr. .... 11. A. ornithopodum

19'. Pínula deltóide a trapeziforme, peciólulo $3-15 \mathrm{~mm}$ compr. 13. A. pentadactylon

18'. Pecíolo e raque pubescentes distalmente.

20. Indúsio com tricomas

2. A. curvatum

20'. Indúsio glabro.

21. Raque com escamas linear-lanceoladas e tricomas

1. A.abscissum

21'. Raque somente com diminutos tricomas.

22. Ápice da pínula longo acuminado-agudo, base da pínula auriculada sobrepondo a raque 9. A. mynsseniae

22'. Ápice da pínula arredondado a obtuso, base da pínula cuneada não sobrepondo a raque 11. A. ornithopodum

1. Adiantum abscissum Schrad., Gott. Gel. Anz.: 872. 1824.

Fig. 1a-c

Plantas terrestres. Caule longo-reptante, 1,59 mm diâm., revestido por escamas linearlanceoladas, castanho-claras a castanho-escuras, ápice acuminado a agudo, margens inteiras a levemente denticuladas, $1,2-3,2 \times 0,2-0,8 \mathrm{~mm}$. Frondes eretas a decumbentes; pecíolo $30-80 \mathrm{~cm} \times$ 2,5-5 $\mathrm{mm}$, cilíndrico a anguloso, sulcado adaxialmente, castanho-escuro a preto, revestido na base por escamas semelhantes às do caule, lanceoladas com base pectinada, castanho-claras a castanho-escuras, ápice agudo, margens inteiras a levemente ciliadas, $0,8-1,5 \times 0,1 \mathrm{~mm}$; lâmina pedada, 3-pinada ou mais dividida, $14-50 \times 25-44 \mathrm{~cm}$, cartácea, verde-escura; raque cilíndrica a angulosa, sulcada adaxialmente, castanho-escura a preta, com escamas linear-lanceoladas e muitos tricomas articulados, dispostos adaxialmente, castanhoclaros, abaxialmente glabra; pinas 2-4 pares, pecioluladas; pina apical conforme; pínulas quadrangulares a deltóides, curtamente pecioluladas, peciólulo com 0,5-1 mm compr., cor do peciólulo passando para a lâmina foliar, ápice arredondado a agudo, base cuneada, margens denteadas, glabras, não articuladas; venação livre, nervuras simples ou furcadas. Soros dispostos principalmente no lado acroscópico das pínulas, 0,4-3×0,5-1,2 mm, 2-10 por pínula; indúsio oblongo, membranáceo, glabro. Material selecionado: Angra dos Reis, Reserva Biológica Praia do Sul, 11.IV.1984, D. Araújo et al. 6202 (GUA). Cachoeiras de Macacu, Distrito de Lagoinha, 15.X.2000, F. Pereira 22.41 (RFA). Macaé, Bicuda Pequena, 12.VI. 2006, S. Winter 360 (RB).

Adiantum abscissum caracteriza-se pela lâmina pedada, 3-pinada e pela presença de escamas lanceoladas com base pectinada, no pecíolo. Difere de A. curvatum Kaulf. por este apresentar tricomas sobre o indúsio. Adiantum ornithopodum C. Presl é outra espécie semelhante, porém difere por ser glabra ou apresentar somente pequenos tricomas articulados avermelhados no pecíolo e na raque. Adiantum mynsseniae J. Prado também pertence a este complexo, mas se diferencia pela presença de 

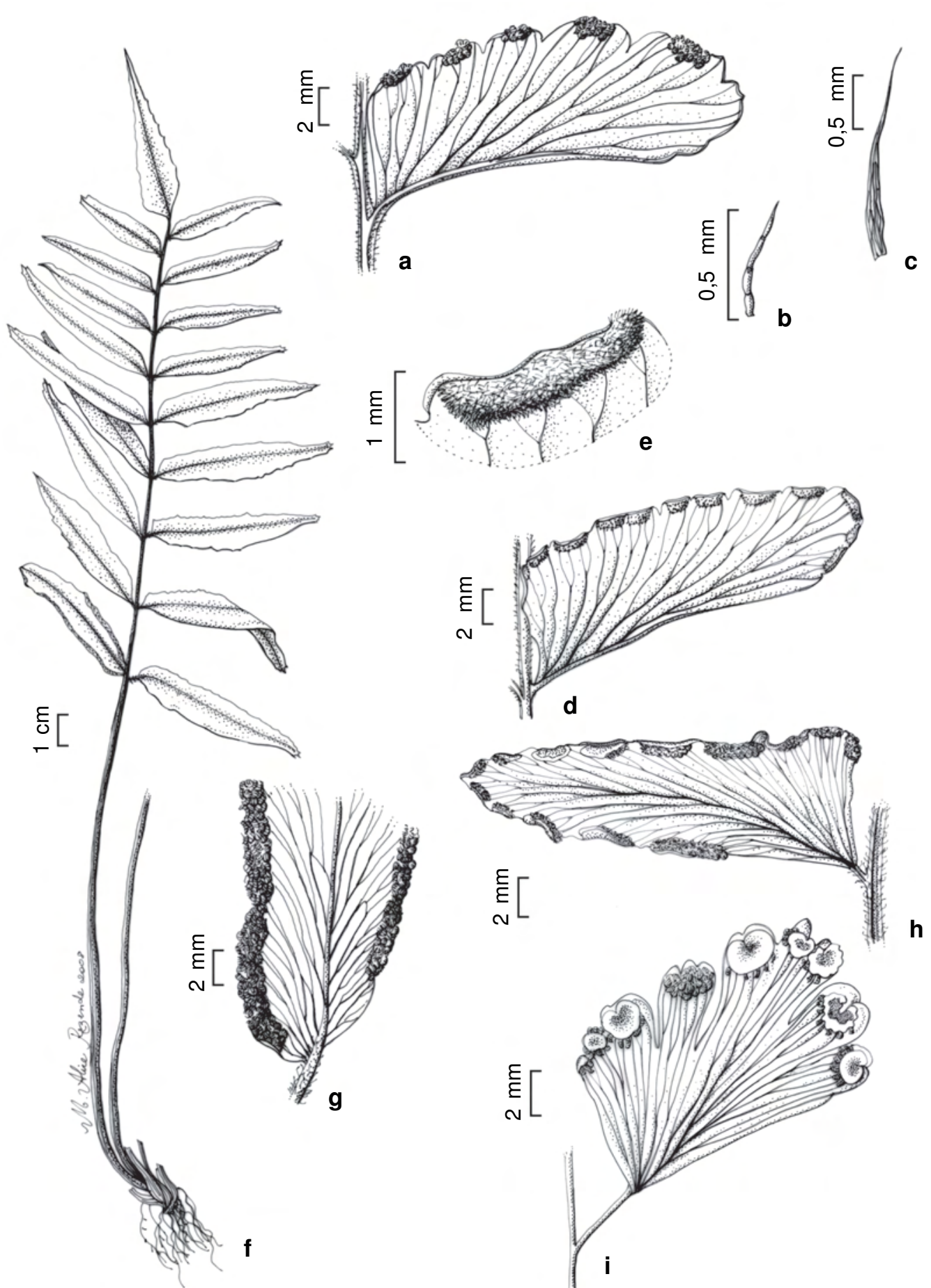

Figura 1 - a-c. Adiantum abscissum Schrad.- a. pínula fértil; b. tricoma da raque; c. escama linear-lanceolada da raque (Jascone 901). d-e. Adiantum curvatum Kaulf. - d. pínula; e. indúsio com tricomas (Braga 874). f-g. Adiantum dolosum Kunze - f. hábito; g. pínula com nervuras anastomosadas (Jascone 232). h. Adiantum latifolium Lam. - pínula fértil (Winter 212). i. Adiantum lorentzii Hieron. - pínula com incisão de $2 / 3$ e lobos lineares (Muker 208).

Figure 1 - a-c. Adiantum abscissum Schrad. - a. fertile pinnule; b. trichome from rachis; c. linear-lanceolate scales from rachis (Jascone 901). d-e. Adiantum curvatum Kaulf. - d. pinnule; e. indusia with trichomes (Braga 874). f-g. Adiantum dolosum Kunze - f. habit; g. pinnule with anastomosing veins (Jascone 232). h. Adiantum latifolium Lam - fertile pinnule (Winter 212). i. Adiantum lorentzii Hieron. - pinnule with deep incisions (ca. 2/3) and linear lobes (Muker 208). 
tricomas diminutos no pecíolo e na raque, base das pínulas auriculada sobrepondo a raque e raquíola, pelo ápice da pínula acuminado-agudo voltado para cima, bem como pela lâmina glauca abaxialmente. Adiantum parallelogramum Vel. ilustrado na "Flora Fluminensis" (Vellozo 1825-1827), é uma representação de A. abscissum, reconhecido pelas pínulas contíguas e soros na face acroscópica das pínulas.

É uma espécie endêmica do Brasil, ocorrendo nos estados do Pará, Ceará, Pernambuco, Alagoas, Bahia, Mato Grosso, Goiás, Minas Gerais, Espírito Santo, Rio de Janeiro, São Paulo, Paraná e Santa Catarina. Ocorre preferencialmente no interior de matas maduras, mas também pode ser encontrada em florestas degradadas de encosta, nas margens de riachos e de estradas, em capoeiras, pastos e sobre afloramentos rochosos. Ocorre isolada ou formando populações densas. Pode ser encontrada em locais sombreados ou expostos ao sol, tanto secos quanto úmidos. No Rio de Janeiro, ocorre em floresta ombrófila densa submontana, montana e aluvial, desde o nível do mar até ca. de 850 metros de altitude.

\section{Adiantum curvatum Kaulf., Enum. Fil.: 202. 1824.}

Fig. 1d-e

Plantas terrestres. Caule longo-reptante, 2 $4 \mathrm{~mm}$ diâm., revestido por escamas lanceoladas, castanho-avermelhadas, ápice agudo, margens levemente denteadas, 1,8-2,5 ×0,2-0,5 mm. Frondes eretas; pecíolo $35 \mathrm{~cm} \times 2,5 \mathrm{~mm}$, cilíndrico, sulcado adaxialmente, castanho-escuro, revestido por escamas lanceoladas, base pectinada, ápice agudo e margens inteiras, e por tricomas castanhoavermelhados, 0,1-0,2 mm compr.; lâmina pedada, 3-pinada, $28 \times 27 \mathrm{~cm}$, cartácea, verde-escura; raque cilíndrico-sulcada, castanho-escura, com escamas e tricomas dispostos adaxialmente, as escamas similares às do pecíolo, os tricomas diminutos, castanho-claros, 0,1-0,2 mm compr., abaxialmente glabra; pinas 1-2 pares, pecioluladas; pina apical conforme; pínulas trapeziforme a deltóides, curtamente pecioluladas ou sésseis, peciólulo com 0,1-1,5 mm compr., cor do peciólulo passando para lâmina foliar, ápice oblongo, base cuneada, margens serreadas, glabras, não articuladas; venação livre, nervuras simples ou furcadas. Soros dispostos no lado acroscópico das pínulas, $0,8-3 \times 0,1-0,2 \mathrm{~mm}, 2-15$ por pínula; indúsio oblongo, membranáceo, com tricomas. Material examinado: Campos dos Goytacazes, Distrito de Morro do Coco, 6.XII.2005, J. Braga 874 (RB).

Esta espécie tem como principais características a lâmina pedada, 3-pinada, raque com tricomas e com escamas lanceoladas de base pectinada, além de tricomas sobre o indúsio. É uma espécie endêmica do Brasil, ocorrendo nos estados do Amazonas, Bahia, Minas Gerais, Rio de Janeiro, São Paulo, Paraná e Santa Catarina. É uma planta tolerante à sombra, ocorrendo principalmente nas bordas das matas. No Rio de Janeiro, cresce na Floresta Estacional de Terras Baixas, ao nível do mar.

3. Adiantum deflectens Mart., Icon. Pl. Crypt.: 94. 1834.

Plantas terrestres ou epipétricas. Caule ereto, 2-3 mm diâm., revestido por escamas linearlanceoladas, castanho-claras com região central preta, ápice agudo a linear, margens inteiras a levemente serreadas, 3-4×0,3-0,5 mm. Frondes decumbentes; pecíolo 6-18 cm $\times 0,2-0,8 \mathrm{~mm}$, cilíndrico, castanhoescuro a preto, revestido na base por escamas semelhantes às do caule; lâmina 1-pinada, 8-40 × 2-5 cm, cartácea, verde-escura; raque cilíndrica a cilíndrico-sulcada, castanho-escura a preta, glabra, geralmente com gemas prolíferas no ápice, às vezes gemas ausentes; pinas 7-14 pares, curtamente pecioluladas, peciólulo com 1-9 mm compr., cor do peciólulo interrompida abruptamente na base da pina, idioblastos facilmente visíveis na face abaxial; pinas flabeladas, ápice arredondado, base cuneada, margens inteiras ou inciso-serreadas, glabras em ambas as faces, articuladas com a raque; venação livre, nervuras simples ou furcadas. Soros dispostos no ápice dos lobos, $1-5 \times 0,2-1 \mathrm{~mm}, 2-13$ por pínula; indúsio oblongo a lunado, membranáceo, glabro.

Material selecionado: Cantagalo, Euclidelândia, 20.II.1984, J. Carauta \& M. Peixoto 4599 (GUA). Itaperuna, Vale do Rio São Domingos, 11.I.1984, J. Carauta \& G. Somner 4595 (GUA). Maricá, Boqueirão, 18.IV.2004, S. Winter 20 (RB).

Adiantum deflectens caracteriza-se principalmente pela lâmina 1-pinada, pecíolo e raque glabros, pinas flabeladas e articuladas, e pela raque prolífera no ápice. Pode ser confundida com Adiantum calcareum Gardner, que é uma espécie também endêmica do Brasil, tendo sido registrada somente para os estados da Bahia, Goiás, Minas Gerais e no Distrito Federal. Adiantum calcareum difere por ser mais delicada, pelas pinas basais flabelado-arredondadas e pelas pinas medianas profundamente inciso-lobadas e curto pecioluladas.

Adiantum deflectens ocorre do México à Argentina, com ampla distribuição no território brasileiro (de Rondônia a São Paulo). Forma grandes populações em locais sombreados. Cresce no 
interior da mata ou em barrancos na borda da floresta. No Rio de Janeiro pode ser encontrada na floresta ombrófila densa montana, floresta ombrófila densa de terras baixas e floresta estacional semidecidual submontana, desde o nível do mar até 600 metros de altitude.

4. Adiantum dolosum Kunze, Linnaea 21:219. 1848.

Fig. 1f-g

Plantas terrestres. Caule curto-reptante, $4 \mathrm{~mm}$ diâm., revestido por escamas lanceoladas, castanho-claras, ápice agudo, margens inteiras, 0,8$1,2 \times 0,1 \mathrm{~mm}$. Frondes eretas; pecíolo $12-28 \mathrm{~cm} \times$ 0,9-2 mm, cilíndrico-anguloso, sulcado adaxialmente, castanho-escuro a preto, revestido na base por escamas semelhantes às do caule e por escamas lanceoladas com base pectinada, castanho-claras a castanho-escuras, ápice agudo, margens inteiras a levemente denticuladas, 0,3-1,5 ×0,1-0,2 mm; lâmina 1-pinada, 14-18×8-19cm, cartácea, verdeclara a verde-escura; raque angulosa a cilíndrica, preta, revestida abaxialmente por escamas lanceoladas, base pectinada, castanho-claras a castanho-escuras, ápice agudo, margem inteira a ciliada, 1-1,2 mm compr., glabrescente na face adaxial, não prolífera no ápice; pinas 4-6 pares, sésseis ou pecioluladas, peciólulo com 1-4 mm compr., cor do peciólulo interrompida abruptamente na base da pina, idioblastos visíveis somente na face adaxial; pina apical conforme; pinas lanceoladas, ápice agudo, base simétrica ou levemente assimétrica (cuneada no lado basiscópico e arredondada no lado acroscópico), margens serreadas, revestidas abaxialmente com escamas lanceoladas com base pectinada, adaxialmente revestida com poucas escamas similares às abaxiais, 1-2 mm compr., não articuladas; venação irregularmente anastomosada. Soros dispostos nos lados basiscópico e acroscópico das pínulas, 1,5-7×0,2-1 mm, 2 por pina, 1 em cada lado alcançando ou não o ápice da pina; indúsio linear contínuo, membranáceo, com tricomas esparsos.

Material selecionado: Engenheiro Paulo de Frontin, Morro Ana, 19.V.2002, M. Guerra \& A. Valente 1592 (RFFP, SP). Nova Iguaçu, Parque Municipal de Nova Iguaçu, 11.VIII.2004, C. Jascone 232 (RFFP).

As principais características diagnósticas de Adiantum dolosum são a lâmina 1-pinada, pecíolo com escamas lanceoladas de base pectinada, nervuras anastomosadas e indúsio linear, contínuo, um de cada lado da pínula. Eventualmente pode ser confundida com A. lucidum (Cav.) Sw. No entanto, esta última apresenta bases da pina com lados desiguais, arredondada na superfície acroscópica e cuneada no lado basiscópico, e veias irregularmente anastomosadas, muitas vezes livre.

Adiantum dolosum ocorre da Venezuela à

Bolívia e Brasil, onde se distribui desde o Acre até São Paulo. É uma espécie ciófila, comum em locais úmidos. Em geral não forma grandes populações. No Rio de Janeiro, é encontrada na floresta ombrófila densa submontana, ocorrendo de 50-400 metros de altitude.

5. Adiantum glaucescens Klotzsch, Linnaea 18: 552. 1844.

Plantas terrestres. Caule curto-reptante, $2-4 \mathrm{~mm}$ diâm., revestido na base por escamas linearlanceoladas, castanho-escuras a pretas, ápice acuminado a agudo, margens inteiras a levemente denticuladas, $1-2,5 \times 0,2-0,7 \mathrm{~mm}$. Frondes eretas; pecíolo $19-60 \mathrm{~cm} \times 0,8-4 \mathrm{~mm}$, anguloso, sulcado adaxialmente, preto, revestido na base por escamas semelhante às do caule, distalmente glabro; lâmina 2-pinada, 14-18 ×13-20 cm, cartácea, verde-escura adaxialmente, glauca abaxialmente; raque angulosa, preta, glabra; pina 2-4 pares, pecioluladas, peciólulo com 0,5-1,5 mm compr., cor do peciólulo interrompida abruptamente na base da pínula, idioblastos visíveis na face adaxial; pínula apical sub-rômbica; pínulas deltóide-dimidiadas, ápice arredondado a agudo, base cuneada, margens denteadas, glabras, articuladas; venação livre, nervuras simples ou furcadas. Soros em ambos os lados das pínulas, 0,6-2,2 $\times 0,5-0,8 \mathrm{~mm}$, 2-10 por pínula; indúsio oblongo, membranáceo, glabro. Material selecionado: Barra do Piraí, 13.IV.1926, F.C. Hoehne \& A. Gehrt (SP). Itatiaia, Chalés Terra Nova, 18.I.1999, J. Prado \& J.C. Yesilyurt 1005 (SP). Rio de Janeiro, Teixeira de Soares, A. Sampaio 780 (R).

Esta espécie caracteriza-se pela lâmina 2-pinada, pecíolo e raque glabros, pínulas glabras em ambas as faces e abaxialmente glaucas. Distribui-se da Venezuela a Bolívia e Brasil, onde ocorre de Roraima a São Paulo. Éuma espécie que cresce na margem de rios e em locais sombreados. No Rio de Janeiro, ocorre na floresta ombrófila densa submontana, de terras baixas e montana, desde o nível do mar até 700 metros de altitude.

6. Adiantum latifolium Lam. in Poir., Encycl. 1: 43. 1783.

Fig. $1 \mathrm{~h}$

Plantas terrestres ou saxícolas. Caule longoreptante, 1,5-4 mm diâm., revestido por escamas lanceoladas, castanho-claras a castanho-escuras, ápice agudo, margens inteiras a levemente serreadas, $1,2-3 \times 0,2-0,5 \mathrm{~mm}$. Frondes eretas; pecíolo $7-45 \mathrm{~cm}$ 
$\times 0,8-2,5 \mathrm{~mm}$, anguloso, sulcado adaxialmente, castanho-escuro a preto, superfície com pequenas projeções, revestido na base por escamas semelhantes às do caule e por escamas aracnóides, castanho-avermelhadas, $0,1-0,3 \mathrm{~mm}$ compr.; lâmina 2-pinada, 12-40×15-40 cm, cartácea, verde-escura; raque angulosa sulcada adaxialmente, castanhoescura a preta, revestida por escamas lanceoladas com base pectinada e escamas aracnóides ambas semelhantes às do pecíolo; pinas 1-4 pares, pecioluladas, peciólulo com $0,8-1,2 \mathrm{~mm}$ compr., cor do peciólulo passando para a base da pínula, idioblastos visíveis adaxialmente; pina terminal subrômbica, mais longa que as laterais; pínulas deltóides a dimidiado-subdimidiadas, ápice agudo, base cuneada, margem serreada a inciso-serreada, glabras, não articuladas, glaucas abaxialmente; venação livre, nervuras simples ou furcadas. Soros dispostos em ambos os lados das pínulas, $1-7 \times 0,1-1,2 \mathrm{~mm}, 2-22$ por pínula; indúsio oblongo, membranáceo, glabro. Material selecionado: Macaé, Bicuda, 5.IX.2005, S. Winter 212 (RB). Mangaratiba, Reserva de Rio das Pedras, 30.XI.1996, L. Sylvestre 1243 (RUSU). Maricá, Boqueirão, 18.IV.2004, S. Winter 11 (RB).

Adiantum latifolium tem como características principais a lâmina 2-pinada, raque com dois tipos de escamas, lanceoladas de base pectinada e aracnóides, pínula glabra em ambas as faces e glauca abaxialmente. Difere de A. glaucescens por esta apresentar o pecíolo e a raque glabros. Adiantum argutum Splitg. demonstra uma grande afinidade com A. latifolium, mas difere por apresentar, na face abaxial das pínulas, escamas setiformes sobre as nervuras. Pode também ser confundido com $A$. intermedium $\mathrm{Sw}$., mas este apresenta apenas escamas estreito-lanceoladas no pecíolo. Adiantum petiolatum Desv. é uma espécie muito semelhante que difere pelos caracteres do rizoma (curto-reptante com frondes aglomeradas) e pela margem erodida $\mathrm{e}$ fimbriada do indúsio. Adiantum falcatum Vel., ilustrado na "Flora Fluminensis"(Vellozo 1825-1827), é uma representação de A. latifolium, reconhecido pela lâmina 2-pinada, pina terminal mais longa que as laterais e pelas pínulas dimidiadas. Adiantum intermedium Sw., citado por Baker (1870) na "Flora Brasiliensis", também corresponde a A. latifolium.

É uma espécie de ampla distribuição, ocorrendo do México à Argentina. No Brasil, é representada desde os estados da região Norte até Santa Catarina. Esta espécie pode ser encontrada em subosques úmidos, nas margens das trilhas, nas proximidades de cachoeiras e mananciais, em capoeiras e em barrancos. Cresce em locais sombreados ou expostos ao sol, podendo formar grandes populações ou crescer isoladamente. No Rio de Janeiro, ocorre na floresta ombrófila densa de terras baixas, na submontana e na montana, desde o nível do mar até 800 metros de altitude.

7. Adiantum lorentzii Hieron. in Engler, Bot. Jahrb. Syst. 22:393. 1896.

Fig. 1i

Plantas terrestres, rupícolas ou saxícolas. Caule subereto, 1-2,5 mm diâm., revestido por escamas linear-lanceoladas, castanho-claras, ápice agudoacuminado, margens inteiras, $1-3 \times 0,1-0,8 \mathrm{~mm}$. Frondes eretas a decumbentes; pecíolo 2,5-21 cm $\times$ 0,1-1 mm, cilíndrico a cilíndrico-sulcado adaxialmente, castanho-escuro, revestido na base por escamas semelhantes às do caule; lâmina 4-pinada, 4,5-30 × 2,2-22 cm, membranácea, verde-escura, glabra; pinas 3-10 pares, pecioluladas, peciólulo longo, $0,8-5 \mathrm{~mm}$ compr., cor do peciólulo passando para base da pínula, pina apical conforme; pínulas flabeladas, ápice arredondado, base cuneada, margens incisodenteadas, incisões chegando a $2 / 3$ do comprimento da pínula, formando lobos lineares, glabras, não articuladas; venação livre, nervuras simples ou furcadas. Soros dispostos no lado distal das pínulas, $0,2-2,2 \times 0,2-1,5 \mathrm{~mm}, 2-10$ por pínula; indúsio reniforme, membranáceo, glabro.

Material selecionado: Angra dos Reis, Ilha Grande, 21.III.2000, F. Pinheiro \& A. Souza 354 (HB). Nova Friburgo, Colégio Anchieta, 10.VII.1976, M. Oliveira \& M. Oliveira (RB 175157). Petrópolis, Serra da Estrela, 31.VIII.1963, Muker 208 (R).

Adiantum lorentzii caracteriza-se pela lâmina 4-pinada, pecíolo e raque glabros, e pelas pínulas com incisões chegando a $2 / 3$ do seu comprimento, formando lobos lineares e glabros em ambas as faces. Difere de $A$. raddianum por este apresentar incisões que chegam somente até metade do comprimento das pínulas, formando lobos arredondados. Pode ser confundida com $A$. poiretii Wikstr., a qual se diferencia por apresentar rizoma longo-reptante, pínulas inteiras, orbiculares a flabeladas e uma substância cerosa amarelada nos esporângios.

Adiantum lorentzii distribui-se do Peru à Argentina, ocorrendo no Brasil desde o Ceará até o Rio Grande do Sul. É uma espécie que típica de matas de encostas, onde é encontrada em locais sombreados ou expostos ao sol. No Rio de Janeiro, ocorre na floresta ombrófila densa de terras baixas, submontana e montana, desde o nível do mar até 850 metros de altitude. 
8. Adiantum macrophyllum Sw., Prodr.: 135. 1788.

Fig. 2a

Plantas terrestres. Caule ereto ou curtoreptante, 3-5 $\mathrm{mm}$ diâm., revestido por escamas lanceoladas, ápice agudo-caudado, margens levemente ciliadas, $2-4 \times 0,4-0,8 \mathrm{~mm}$. Frondes eretas a decumbentes; pecíolo $8,5-35 \mathrm{~cm} \times 0,2-2 \mathrm{~mm}$, anguloso, sulcado adaxialmente, preto, com escamas semelhantes às do caule, glabro distalmente; lâmina 1-pinada, 10,5-24×8-14 cm, cartácea, verde-clara, glauca abaxialmente; raque angulosa, sulcada adaxialmente, preta, glabra, não prolífera no ápice; pinas 3-6 pares, curtamente pecioluladas ou subsséseis, peciólulo muito curto $0,5-1 \mathrm{~mm}$ compr., cor do peciólulo passando para a base da pina, idioblastos visíveis em ambas as faces, pina apical conforme; pinas oval-deltóides, falcadas, ápice agudo, base obtusa a cordada, margens ligeiramente serreadas a inciso-serreadas, glabras em ambas as faces, não articuladas; venação livre, nervuras furcadas. Soros dispostos em ambos os lados das pínulas, lineares, $1-5 \mathrm{~cm} \times 1-1,5 \mathrm{~mm}, 2$ por pina, $1 \mathrm{em}$ cada margem, alcançando ou não o ápice da pina; indúsio linear, contínuo, membranáceo, glabro.

Material selecionado: Petrópolis, Serra dos Órgãos, $A$. Glaziou 3566 (RB). Rio De Janeiro, A. Glaziou 2317 (RB). Volta Redonda, Parque Municipal do Ingá, 05.I.2007, V. Souza 58 (HB).

Adiantum macrophyllum caracteriza-se pela lâmina 1-pinada, pinas oval-deltóides, glabras em ambas as faces e glaucas abaxialmente, bem como pelo indúsio linear contínuo, um em cada margem da pina.

Distribui-se do México à Argentina, ocorrendo no Brasil desde Roraima até São Paulo. É uma planta que ocorre em locais sombreados, no interior das matas. No Rio de Janeiro, pode ser encontrada na floresta ombrófila densa de terras baixas, submontana e montana, desde onível do mar até 800 metros de altitude.

\section{Adiantum mynsseniae J. Prado, Amer. Fern J.} 94(2): 112. 2004.

Fig. 2b-e

Plantas terrestres. Caule longo-reptante, 3-6 mm diâm., revestido por escamas lanceoladas, castanhoclaras a avermelhadas, ápice agudo, margens inteiras a levemente denticuladas $1-3 \times 0,1-0,5 \mathrm{~mm}$. Frondes eretas a decumbentes; pecíolo $25-57 \mathrm{~cm} \times 3-4 \mathrm{~mm}$, anguloso, sulcado adaxialmente, preto, revestido na base por escamas semelhantes às do caule, nas porções mediana e distal com tricomas castanhoclaros a avermelhados, $0,1-0,3 \mathrm{~mm}$ compr.; lâmina pedada, 3-4-pinada, 20-45 × 25-45 cm, cartácea, verde-clara a verde-escura, glauca abaxialmente; raque angulosa, sulcada adaxialmente, preta, revestida por tricomas avermelhados semelhantes aos do pecíolo; pinas 2-3 pares, pecioluladas, peciólulo com 1-3 mm compr., cor do peciólulo passando para a lâmina foliar; pina apical conforme; pínulas trapeziformes, ápice agudo, longo-acuminado, voltado para cima, base auriculada sobrepondo a raque, margens inciso-denteadas, glabras, não articuladas; venação livre, nervuras simples ou furcadas. Soros dispostos em ambos os lados das pínulas, 0,6-1,2 $\times 0,1-1,5 \mathrm{~mm}, 1-18$ por pínula; indúsio oblongo, membranáceo, glabro.

Material examinado: Mangaratiba, Reserva de Rio das Pedras, 16.VIII.2001, C.M. Mynssen 356 (RB). Paraty, Serra de Paraty, VI.1975, P. Ochioni 7559 (RFA).

Esta espécie distingue-se pela lâmina pedada, 3-5-pinada na base e 2-pinada distalmente, tricomas diminutos no pecíolo e na raque, base das pínulas auriculada e sobrepondo a raque e a raquíola, pelo ápice da pínula agudo, longo-acuminado voltado para cima, pela lâmina glauca abaxialmente, e pelas pínulas e indúsios glabros. Adiantum mynsseniae pertence ao complexo de A. trapeziforme L. (espécie cultivada no Brasil), no qual também estão inseridas A. abscissum, A. curvatum, A. mathewsianum Hook., A. ornithopodum, A patens Willd. e A. pentadactylon Lagsd. \& Fisch., que ocorrem no Brasil. Destas, a mais semelhante à $A$. mynsseniae é $A$. abscissum, que pode se diferenciar por apresentar lâmina pedada, 3-pinada, além da presença no pecíolo de escamas lanceoladas com base pectinada. Outra espécie semelhante é A. curvatum, que, no entanto, apresenta tricomas sobre o indúsio e base das pínula não auriculada. Adiantum ornithopodum, por sua vez, difere por ser glabra ou apresentar somente pequenos tricomas articulados avermelhados no pecíolo e na raque. A. pentadactylon também é uma espécie semelhante, mas se diferencia pela lâmina pedada, 3-pinada, pelo pecíolo e raque glabros, pínulas deltóide-trapeziformes. Em geral, $A$. mynsseniae diferencia-se das outras espécies do complexo devido à presença de tricomas diminutos no pecíolo e na raque, base das pínulas auriculada sobrepondo a raque e raquíola, pelo ápice da pínula acuminado-agudo voltado para cima, bem como pela lâmina glauca abaxialmente.

Adiantum mynsseniae é endêmica do Brasil, ocorrendo em Minas Gerais, Rio de Janeiro e São Paulo. É uma planta tolerante à sombra ou totalmente ciófila, podendo ser encontrada em subosques de matas densas e margens de trilhas, onde forma densas populações. No Rio de Janeiro, ocorre na floresta ombrófila densa submontana, de 50 até 400 metros de altitude. 

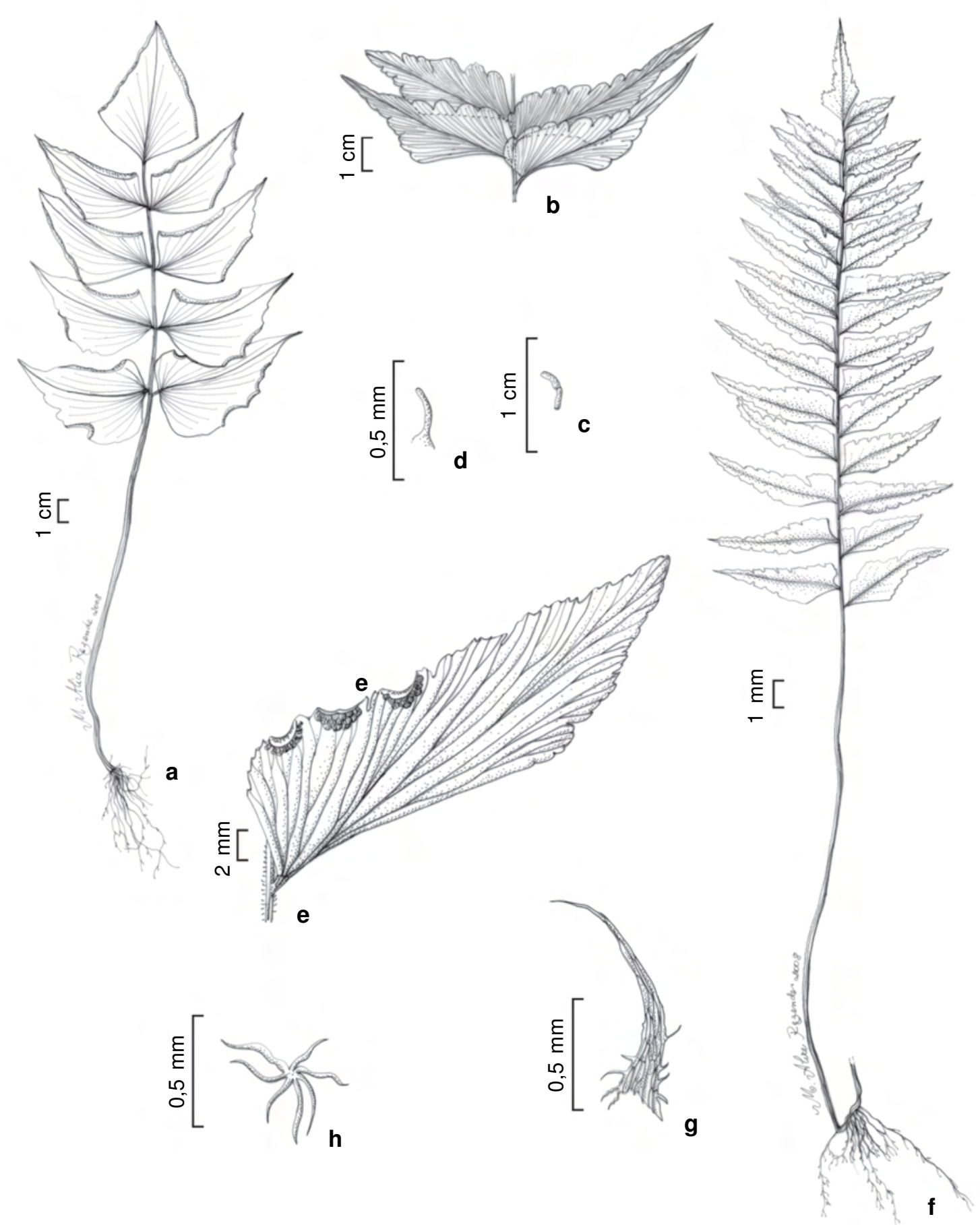

Figura 2 - a. Adiantum macrophyllum Sw. - hábito (Souza 58). b-e. Adiantum mynsseniae J. Prado - b. inserção das pínulas; c-d. tricomas da raque; e. pínula fértil (Mynssen 356). f-h. Adiantum obliquum Willd. - f. hábito; g. escama da raque linear-laceolada com base pectinada; h. escama aracnóide do pecíolo (Braga 6191).

Figure 2 - a. Adiantum macrophyllum Sw. - habit (Souza 58). b-e. Adiantum mynsseniae J. Prado - b. insertion of pinnules; c-d. trichomes from rachis; e. fertile pinnule (Mynssen 356). f-h. Adiantum obliquum Willd. - f. habit; g. linear-lanceolated scales with pectinate base from rachis; h. arachnoid scale from petiole (Braga 6191). 
10. Adiantum obliquum Willd., Sp. Pl. 5: 429. 1810.

Fig. 2f-h

Plantas terrestres. Caule curto-reptante, $2-4 \mathrm{~mm}$ diâm., revestido por escamas linear-lanceoladas, castanho-claras a castanho-escuras, ápice agudo, margens inteiras a levemente denticuladas, 1,2-3,2 $\times 0,1-0,8 \mathrm{~mm}$. Frondes eretas a decumbentes; pecíolo 8-20 cm $\times 1-3 \mathrm{~mm}$, anguloso, sulcado adaxialmente, preto, revestido na base por escamas linearlanceoladas, base pectinada, ápice agudo, margens inteiras a levemente serreadas, $1-1,5 \times 0,1 \mathrm{~mm}$ e por escamas aracnóides, castanho-escuras; lâmina 12-pinada, 11-27×6-20 cm, cartácea, verde-escura, com idioblastos oblíquos e conspícuos entre as nervuras em ambas as faces; raque angulosa, preta, apresentando tricomas, castanho-escuros, $0,1-0,2 \mathrm{~mm}$ compr. e escamas linear-lanceoladas, base pectinada, 1-1,2 mm compr., não prolífera no ápice; quando 2pinada, 1-3 pares, pina apical conforme; quando 1pinada, pinas lanceoladas, não dimidiadas, curtamente pecioluladas, peciólulo com $0,1-0,3 \mathrm{~mm}$ compr. ou pinas sésseis, cor do peciólulo passando para a lâmina foliar, 7-14 pares, não falcadas, ápice agudo a arredondado, base cuneada, margens duplo serreadas, abaxialmente com escamas filiformes sobre as nervuras, base pectinada, não articuladas; venação livre, nervuras furcadas. Soros dispostos em ambos os lados das pínulas, $0,8-1 \times 0,1-0,2 \mathrm{~mm}, 3-25$ por pínula; indúsio oblongo, membranáceo, glabro.

Material selecionado: Angra dos Reis, 27.VII.1959, G. Felipe 3 (SP). Itatiaia, Rodovia Presidente Dutra, 1.XII.2001, P. de Sousa 80 (GUA). Rio das Ostras, Reserva Biológica da União, 23.VIII.2006, S. Winter 410 (RB).

Adiantum obliquum diferencia-se pela lâmina 1(-2)-pinada, pelo pecíolo com dois tipos de escamas, sendo escamas lanceoladas com base pectinada e escamas aracnóides, e pelas pínulas lanceoladas, não dimidiadas, com ápice agudo e face abaxial com escamas filiformes de base pectinada. Há alguns registros de A. obliquum que fogem um pouco o padrão morfológico da espécie. Tais espécimes encontram-se no herbário do Jardim Botânico do Rio de Janeiro e são de uma mesma localidade, a Reserva Biológica União. Provavelmente estes espécimes podem se tratar de elementos híbridos, porém mais estudos seriam necessários para confirmar este fato.

É uma espécie de ampla distribuição, ocorrendo do México à Bolívia e Brasil, onde pode ser encontrada do Amapá ao Paraná. Trata-se de uma planta que se desenvolve em terrenos íngremes e úmidos no interior das matas de baixadas e na base de morrotes. Pode ser ciófila ou tolerante à sombra, formando grandes populações ou ocorrendo isolada. No Rio de Janeiro, é encontrada na floresta ombrófila densa de terras baixas e submontana, desde o nível do mar até 400 metros de altitude.

11. Adiantum ornithopodum C. Presl, Tent. Pterid.: 158. 1836.

Plantas terrestres. Caule curto-reptante, 1,5$5 \mathrm{~mm}$ diâm., revestido por escamas lanceoladas, castanho-claras a avermelhadas, ápice agudo e sinuoso, margens denteadas, $1-4,5 \times 0,1-0,5 \mathrm{~mm}$. Frondes eretas a decumbentes; pecíolo 30-72 $\mathrm{cm} \times$ 2,5-4 mm, anguloso, sulcado adaxialmente, preto, glabro ou com tricomas articulados, castanhoclaros a avermelhados, 0,1-0,2 mm compr.; lâmina pedada, 3-4-pinada, 30-40 × 26-30 cm, cartácea, verde-escura, idioblastos pequenos na face abaxial, não visíveis na face adaxial; raque angulosa, sulcada adaxialmente, preta, glabra ou com raros tricomas avermelhados esparsos; pinas 3-4 pares, pecioluladas, peciólulo curto, $0,1-0,25 \mathrm{~mm}$ compr., cor do peciólulo passando para base da pínula; pina terminal sub-rômbica; pínulas quadrangulartrapeziformes, ápice arredondado-obtuso, base cuneada, não sobrepondo a raque e a raquíola, margens inciso-serreadas a lobadas, glabras em ambas as faces, não articuladas; venação livre, nervuras simples ou furcadas. Soros dispostos em ambos os lados das pínulas, $0,8-4 \times 0,2-1 \mathrm{~mm}, 2-16$ por pínula; indúsio oblongo, membranáceo, glabro. Material selecionado: Itaperuna, Raposo, 10.XI.2002, G. Valente et al. 880 (SP). Rio Claro, Lídice, 16.XI.2001, F. Pereira 01.128 (RFA). Volta Redonda, Parque Municipal do Ingá, 5.I.2007, V. Souza 56 (HB).

Adiantum ornithopodum pode ser reconhecido pela lâmina pedada, 3-4-pinada, pecíolo glabros ou com pequenos tricomas vermelhos, esparsos, pelas pínulas quadrangular-trapeziformes, glabras em ambas as superfícies e pelo indúsio glabro. Difere de A. curvatum. por este apresentar tricomas sobre o indúsio. Outra espécie muito semelhante é $A$. mynsseniae, que também pertence ao mesmo complexo, mas que se diferencia pela presença de tricomas diminutos no pecíolo e na raque, pela base auriculada das pínulas sobrepondo a raque e raquíola, pelo ápice da pínula agudo, longo-acuminado voltado para cima, e pela lâmina glauca abaxialmente. Pode ser confundido com A. abscissum, mas este difere por apresentar lâmina pedada, 3-pinada e escamas lanceoladas de base pectinada, no pecíolo.

Adiantum ornithopodum ocorre no Paraguai, Bolívia e Brasil, onde pode ser encontrada desde a Bahia até São Paulo. É uma espécie tolerante à sombra 
ou completamente ciófila. No Rio de Janeiro, ocorre na floresta ombrófila densa de terras baixas e submontana, do nível do mar até 400 metros de altitude.

12. Adiantum papillosum Handro, Loefgrenia 14: 1.1964.

Fig. 3a-c

Plantas terrestres. Caule longo-reptante, $5-8 \mathrm{~mm}$ diâm., revestido por escamas linear-lanceoladas, castanho-claras a castanho-escuras, ápice agudo, margens inteiras, $1,2-6 \times 0,1-0,7 \mathrm{~mm}$. Frondes eretas a decumbentes; pecíolo $22-120 \mathrm{~cm} \times 2,5-5 \mathrm{~mm}$, cilíndrico, preto, revestido na base por escamas semelhantes às do caule, distalmente glabro; lâmina pedada, 3-5 pinada, 30-36 × 22-30 cm, cartácea, verde-escura; raque e raquíola cilíndricas, pretas, revestidas por tricomas avermelhados, $0,1-0,2 \mathrm{~mm}$ e por escamas lanceoladas, esparsas, castanhoescuras, ápice agudo, margens inteiras a levemente denteadas, $1-2,5 \times 0,3-0,5 \mathrm{~mm}$; pinas 3-5 pares, pecioluladas, peciólulo com 3-9 mm compr., com tricomas e escamas semelhante aos da raque, cor do peciólulo interrompida na base da pínula; pina apical conforme; pínulas deltóides a rômbicas ápice agudo, base truncada a cuneada, margens serreadas, revestidas por tricomas avermelhados na base da pínula, articuladas; venação livre, nervuras simples ou furcadas. Soros dispostos em ambos os lados das pínulas, $0,2-2 \times 0,1-0,8 \mathrm{~mm}, 2-40$ por pínula; indúsio reniforme a oblongo, membranáceo, glabro.

Material examinado: Santa Maria Madalena, Rifa, 24.III.1955, E. Pereira 1333 (HB).

Adiantum papillosum tem como principais características a lâmina pedada, 3-5-pinada, raque e raquíola com diminutos tricomas vermelhos e escamas lanceoladas, e base da pínula com tricomas avermelhados. Difere de A. subcordatum Sw. por este apresentar pecíolo, raque e pínulas glabros.

Adiantum papillosum é endêmica do Brasil, ocorrendo nos estados de Minas Gerais, Espírito Santo, Rio de Janeiro, além de, provavelmente, São Paulo e Paraná. Trata-se de uma espécie terrrícola, que ocorre em ambientes úmidos. No Rio de Janeiro, cresce na floresta ombrófila densa montana, ca. de 600 metros de altitude.

13. Adiantum pentadactylon Langsd. \& Fisch., Ic. Fil.: 22, tab. 25. 1810.

Plantas terrestres. Caule curto-reptante, $2-5 \mathrm{~mm}$ diâm., revestido por escamas lanceolado-filiformes, castanho-claras a castanho-escuras, ápice agudo, sinuoso, margens inteiras a levemente crenadas, 0,6$3,5 \times 0,1-0,5 \mathrm{~mm}$. Frondes eretas a decumbentes; pecíolo $18-50 \mathrm{~cm} \times 1-4 \mathrm{~mm}$, anguloso, sulcado adaxialmente, castanho-escuro a preto, revestido na base por escamas semelhantes às do caule, glabro distalmente; lâmina pedada, 3-pinada, 18-30×17$45 \mathrm{~cm}$, cartácea, verde-escura, muitas vezes glauca abaxialmente; raque angulosa, sulcada adaxialmente, castanho-escura a preta, glabra; pina 2-3 pares, pecioluladas, peciólulos longo 3-15 mm compr., cor do peciólulo passando para a lâmina foliar; pina apical conforme; pínulas deltóide-trapeziformes, ápice arredondado a agudo, base cuneada, margens incisoserreadas, glabras, não articuladas; venação livre, nervuras simples ou furcadas. Soros dispostos em ambos os lados das pínulas, 0,4-4×0,3-2 mm, 2-25 por pínula; indúsio oblongo, membranáceo, glabro. Material selecionado: Angra dos Reis, Ilha Grande, 14.XII.1983, D. Araújo 5885 (GUA). Santa Maria Madalena, 28.XI.1987, J. Carauta \& R. Montella 2770 (RB). Vassouras, Morro Azul, 25.VI.1944, F. Vianna s.n. (R 117703).

Adiantum pentadactylon caracteriza-se pela lâmina pedada, 3-pinada, pecíolo e raque glabros e pelas pínulas deltóide-trapeziformes com peciólulos longos, de 3-15 mm de comprimento. Adiantum trapeziforme L. é muito semelhante, mas difere por ter a lâmina pedada, pínulas articuladas, cor do peciólulo parando abruptamente na base da lâmina e pínulas abaxialmente não glaucas.

Adiantum pentadactylon é uma espécie endêmica do Brasil, ocorrendo nos estados de Minas Gerais, Rio de Janeiro, São Paulo, Paraná, Santa Catarina e Rio Grande do Sul. Pode ser encontrada próxima às margens de rios ou em barrancos na floresta, sendo caracterizada como heliófila ou tolerante à sombra. No Rio de Janeiro, ocorre na floresta ombrófila densa de terras baixas, submontana e montana, desde o nível do mar até 800 metros de altitude.

14. Adiantum pulverulentum L., Sp. Pl. 2: 1096. 1753.

Fig. 3d-f

Plantas terrestres ou rupícolas. Caule longoreptante, 3-6 mm diâm., revestido por escamas linear-lanceoladas, castanho-claras a castanhoescuras, ápice agudo, margens inteiras a fimbriadas, $1-2,5 \times 0,1-0,7 \mathrm{~mm}$. Frondes eretas; pecíolo $12-$ $48 \mathrm{~cm} \times 1-2 \mathrm{~mm}$, cilíndrico a anguloso, sulcado adaxialmente, castanho-escuro, revestido na base por escamas lanceoladas, castanho-escuras, ápice agudo, margens denteado-fimbriadas, $1-4 \times 0,3-$ 0,4-1 mm, e por escamas aracnóides, $0,4-0,8 \times 0,2$ 0,4 mm; lâmina 2-pinada, 14-30×15-28 cm, cartácea, 


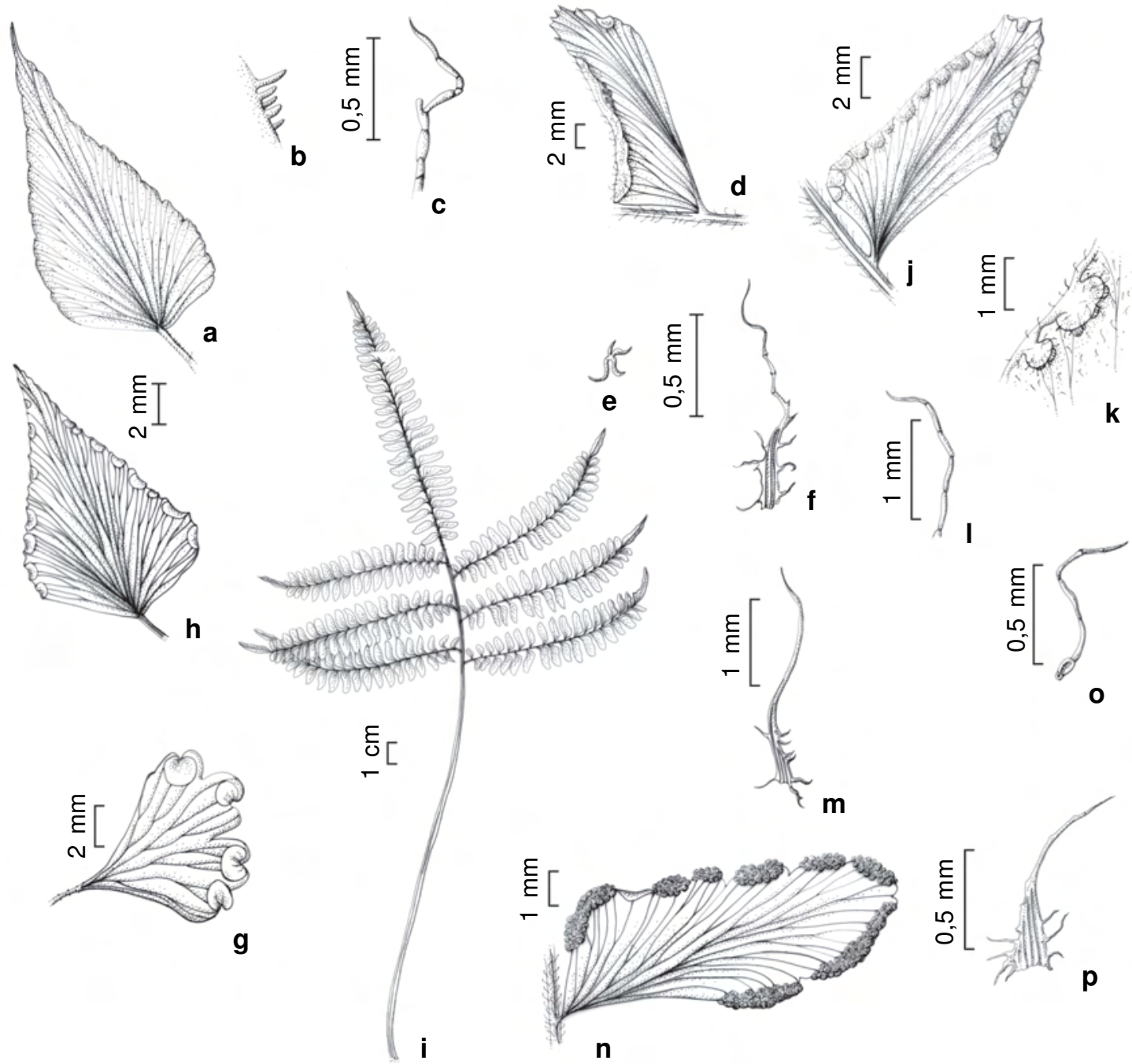

Figura 3 - a-c. Adiantum papillosum Handro - a. pínula estéril; b. inserção dos tricomas na raque e na raquíola; c. escama da raque e raquíola (Pereira 1333). d-f. Adiantum pulverulentum L. - d. pínula fértil; e. escama aracnóide da raque; f. escama lanceolada com base pectinada da raque (Mynssen et al. 33). g. Adiantum raddianum C. Presl pínula com incisão de $1 / 2$ e lobos arredondados (Winter 31). h. Adiantum subcordatum Sw. - pínula fértil (Carauta 1382). i-m. Adiantum terminatum Kunze ex Miq. - i. hábito; j. pínula fértil; k. detalhe do indúsio; 1. tricoma articulado da face abaxial da pínula e do indúsio; m. escama lanceolada com base pectinada da raque (Hoehne s.n.). n-p. Adiantum windischii J. Prado - n. pínula fértil; o. tricoma septado da face abaxial da pínula; p. escama lanceolada com base pectinada da raque (Pabst 4558).

Figure 3 - a-c. Adiantum papillosum Handro - a. sterile pinnule; b. trichomes insertion on rachis and raquiola c. scales from rachis and raquiola (Pereira 1333). d-f. Adiantum pulverulentum L. - d. fertile pinnule; e. arachnoid scales from rachis, f. lanceolate scales with pectinate base from rachis (Mynssen et al. 33). g. Adiantum raddianum C. Presl - pinnule with short incisions (ca. 1/2) and rounded lobes (Winter 31). h. Adiantum subcordatum $\mathrm{Sw}$ - fertile pinnule (Carauta 1382). i-m. Adiantum terminatum Kunze ex Miq. - i. habit; j. fertile pinnule $\mathrm{k}$. indusia detail 1 . articulated trichome from the abaxial surface of pinnule and indusia. m. lanceolate scales with pectinate base from rachis (Hoehne s.n.). n-p. Adiantum windischii J. Prado - n. fertile pinnule; o. septate trichomes from abaxial suface of the pinnule; p. lanceolated scales with pectinate base from rachis (Pabst 4558). 
verde-clara, idioblastos visíveis em ambas as superfícies; raque cilíndrica a angulosa, castanhoescura, com escamas aracnóides, 0,2-0,5 mm compr. e escamas lanceoladas com base pectinada, 1-1,5 $\times 0,1-0,3 \mathrm{~mm}$, face adaxial glabra; pinas $2-7$ pares, pecioluladas; peciólulo com $0,2-1 \mathrm{~mm}$ compr., cor do peciólulo passando para a lâmina foliar, pina apical conforme; pínulas dimidiado-falcada, ápice agudo, base cuneada, margens inciso-serreadas, abaxialmente revestida por escamas com base pectinada sobre as nervuras, não articuladas; venação livre, nervuras furcadas. Soro disposto no lado acroscópico das pínulas, 0,7-14 $\mathrm{mm} \times 0,1-$ 0,8 mm, 1-(2) por pínula; indúsio linear, contínuo, falcado, membranáceo, glabro ou com tricomas.

Material selecionado: Angra dos Reis, Ilha Grande, 15.XII.1999, M. Guerra \& F. Pinheiro 1357 (HB). Bom Jesus de Itabapoana, Carabuçu, 12.IX.1982, J. Carauta et al. 4388 (HB). Campos dos Goytacazes, Morro do Coco, 16.VII.2001, R. Mello-Silva \& A. Lobão 1828 (SP).

Adiantum pulverulentum caracteriza-se principalmente pela lâmina 2-pinada, pelo indúsio linear, contínuo e falcado, e pela presença de dois tipos de escamas na raque, escamas lanceoladas com base pectinada e escamas aracnóides. Ocorre do México ao Paraguai e Brasil, onde pode ser encontrada desde a região Norte até São Paulo. Adiantum pulverulentum é uma espécie aparentemente indiferente às condições de luminosidade, podendo ser caracterizada como heliófila, tolerante à sombra ou ciófila. Pode ser encontrada em capoeiras, em terrenos íngremes, no interior e bordas de matas, ao longo de trilhas ou nas margens de rios, formando grandes populações. No Rio de Janeiro, ocorre na floresta ombrófila densa de terras baixas, submontana ou montana, do nível do mar até 800 metros de altitude.

15. Adiantum raddianum C. Presl, Tent. Pterid.: 158. 1836.

Fig. $3 g$

Plantas terrestres, rupícolas ou saxícolas. Caule curto-reptante, 1-3 mm diâm., revestido por escamas linear-lanceoladas, castanho-claras a douradas, ápice agudo, margens inteiras, $0,8-3 \times$ $0,1-0,5 \mathrm{~mm}$. Frondes eretas a decumbentes; pecíolo 3-18 cm $\times 0,1-2 \mathrm{~mm}$, cilíndrico-anguloso, sulcado adaxialmente, castanho-escuro a preto, revestido na base por escamas semelhantes às do caule, distalmente glabro; lâmina 3-pinada, 3-26×6-30 cm, cartácea a membranácea, verde-clara; raque deflexa, cilíndrico-angulosa, sulcada adaxialmente, castanho-escura a preta, glabra; pinas 4-15 pares, pecioluladas, peciólulo com 1-2 mm compr., cor do peciólulo passando para base da pínula; pina apical conforme; pínulas obovais a flabeladas, ápice arredondado, base cuneada e usualmente assimétrica, margens serreadas a inciso-denteadas, incisões de até $1 / 2$ do comprimento da pínula, formando lobos arredondados, glabras, não articuladas; venação livre, nervuras simples ou furcadas. Soros no lado acroscópico das pínulas, $0,8-1,8 \times 0,5-1,5 \mathrm{~mm}, 2-8$ por pínula; indúsio reniforme, membranáceo, glabro. Material selecionado: Itatiaia, Estrada para Visconde de Mauá, 29.V.2006, S. Winter 238 (RB). Macaé, Bicuda, 5.IX.2006, S. Winter 208(RB). Maricá, Inoã, 9.V.2004, S. Winter 31 (RB).

Adiantum raddianum pode ser reconhecido pela lâmina 3-pinada, pecíolo, raque e pínulas glabros, pínulas obovais a flabeladas, com incisões até $1 / 2$ do comprimento da pínula, formando lobos arredondados. Difere de A. lorentzii por este apresentar incisões que chegam até $2 / 3$ do comprimento da pínula, formando lobos lineares. Pode ser confundida com A. poiretii, a qual pode ser diferenciada por apresentar rizoma longoreptante e pínulas inteiras, orbiculares a flabeladas, com substância cerosa amarela nos esporângios. Adiantum trapeziforme Vell., ilustrado na "Flora Fluminensis" (Vellozo 1825-1827), é uma representação de A. raddianum, reconhecido pelas pínulas flabeladas e soros reniformes.

Adiantum raddianum ocorre do México ao Uruguai e é uma espécie largamente cultivada em todo o mundo. No Brasil encontra-se amplamente distribuída, ocorrendo praticamente em todos os estados. Trata-se de uma planta indiferente às condições de luminosidade, podendo ser caracterizada como heliófila, tolerante à sombra ou ciófila, e que cresce em capoeiras, matas de encostas, barrancos, às margens de riachos e brejos, em paredões rochosos próximos a cachoeiras e às margens de estradas. Forma densas populações ou pode ocorrer isoladamente. No Rio de Janeiro, ocorre na floresta ombrófila densa de terras baixas, submontana e montana e em florestas estacionais semideciduais, desde o nível do mar até 800 metros de altitude.

16. Adiantum serratodentatum Humb. \& Bonpl. ex Willd., Sp. Pl. 5: 445. 1810.

Plantas terrestres. Caule longo-reptante, $1-4 \mathrm{~mm}$ diâm., revestido por escamas lanceoladas, castanhoclaras, ápice agudo, sinuoso, margens inteiras a levemente denteadas, $1-1,5 \times 0,2-0,5 \mathrm{~mm}$. Frondes eretas; pecíolo 9-60 $\mathrm{cm} \times 0,8-2,5 \mathrm{~mm}$, anguloso, sulcado adaxialmente, castanho-escuro a preto, revestido na 
base por escamas semelhantes às do caule e, nas outras porções, por escamas lanceoladas com base pectinada, castanho-escuras, ápice agudo, margens denteadas, 1,5-4×0,2-0,6 mm e escamas aracnóides, castanho-claras, ápice agudo, margens inteiras a levemente denteadas, $0,4-1 \times 0,3-0,5 \mathrm{~mm}$; lâmina 2pinada, 7-40 × 6-27 cm, cartácea, verde-clara, idioblastos visíveis em ambas às faces; raque angulosa sulcada adaxialmente, castanho-escura a preta, revestida por escamas aracnóides com 0,2$0,5 \mathrm{~mm}$ compr. e escamas lanceoladas, base pectinada, 2-3 $\times 0,1-0,2 \mathrm{~mm}$; pinas $4-11$ pares, pecioluladas, peciólulo com $0,1-0,3 \mathrm{~mm}$ compr., cor do peciólulo passando para a base da pínula; pina apical conforme; pínulas dimidiadas, ápice arredondado, base cuneada, margens serreadas e conspicuamente revolutas nas pínulas férteis, nervuras revestidas abaxialmente por esparsas escamas linearlanceoladas, base pectinada e esparsas escamas aracnóides, 0,5-1 mm compr., não articuladas; venação livre, nervuras simples ou furcadas. Soros dispostos em ambos os lados das pínulas, 0,5-2,5 $\times$ 0,1-1 mm, 2-10 por pínula; indúsio oblongo, membranáceo, glabro.

Material selecionado: Angra dos Reis, Ilha Grande, 17.XII.2000, M. Pinheiro et al. 665 (HB). Maricá, Inoã, 9.V.2004, S. Winter 33 (RB). Silva Jardim, Gaviões, 15.III.1998, M. Braga \& E. Conceição 1 (RB).

Adiantum serratodentatum caracteriza-se pela lâmina 2-pinada, pela raque com dois tipos de escamas, escamas lanceoladas com base pectinada e muitas escamas aracnóides, e pelas pínulas dimidiadas revestidas abaxialmente por escamas linear-lanceoladas com base pectinada e por esparsas escamas aracnóides.

Ocorre da América Central à Argentina e Brasil, onde pode ser encontrada desde os estados da região Norte até o Paraná. É uma espécie heliófila, semiciófila ou ciófila, que forma grandes populações ou ocorre isoladamente. Cresce em solos úmidos ou secos, em capoeiras ou florestas maduras, tanto no interior quanto na borda, ao longo de trilhas, entorno de rios e em relevos íngremes. Pode ser encontrada em solo arenoso ou argiloso. No Rio de Janeiro, ocorre na floresta ombrófila densa de terras baixas, submontana e montana, desde o nível do mar até 800 metros de altitude.

17. Adiantum subcordatum Sw., Kongl. Vet. Akad. Handl.: 75. 1817.

Fig. 3h

Plantas terrestres. Caule longo-reptante, $4-6 \mathrm{~mm}$ diâm., revestido por escamas lanceoladas, castanhoclaras a avermelhadas, ápice agudo, margens inteiras a levemente denteadas, $1,2-7 \times 0,1-0,8 \mathrm{~mm}$. Frondes eretas a decumbentes; pecíolo $30-100 \mathrm{~cm} \times 2,5-5 \mathrm{~mm}$, cilíndrico, castanho-escuro a negro, revestido na base por escamas semelhantes às do caule, distalmente glabro; lâmina pedada, 3-4-pinada, 30-40× 27$40 \mathrm{~cm}$, cartácea, verde-escura; raque e raquíola cilíndricas, castanho-escuras, glabras; pinas 5-9 pares, pecioluladas, peciólulo com $2 \mathrm{~mm}$ até $1,5 \mathrm{~cm}$ compr., cor do peciólulo não passando para a base da pínula, pina apical conforme; pínulas deltóides, ápice agudo, base truncada a cuneada, margens inciso-denteadas, articuladas; venação livre, nervuras furcadas. Soros dispostos em ambos os lados das pínulas, $0,5-3 \times 0,2-1,5 \mathrm{~mm}, 2-36$ por pínula; indúsio reniforme, membranáceo, glabro.

Material selecionado: Petrópolis, São José do Rio Preto, 18.XIII.1971, J. Carauta 1382 (R). Rio Bonito, Fazenda Três Cachoeiras, 25.IX.1977, P. Achette 390 (R). Santa Maria Madalena, Pedra do Boi, 24.III.2002, P. Fiaschi et al. 1036 (SP).

Adiantum subcordatum pode ser facilmente reconhecido pela a lâmina pedada, 3-4-pinada, pecíolo, raque e raquíola glabros, e pelas pínulas deltóides e glabras em ambas as faces. Difere de $A$. papillosum por este apresentar escamas e tricomas na raque e raquíola e tricomas na base da pínula. A espécie pode ser confundida com A. tetragonum Schrad., que se difere por apresentar tricomas ao longo da costa adaxial e pela cor do peciólulo passando para a base da lâmina. Adiantum conicum Vel. ilustrado na "Flora Fluminensis" (Vellozo 18251827) é uma representação de A. subcordatum, reconhecido pela lâmina 3-pinada e pínulas deltóides com a base cuneada.

Adiantum subcordatumé endêmica do Brasil, ocorrendo nos estados da Bahia, Minas Gerais, Espírito Santo, Rio de Janeiro e São Paulo. Cresce no interior de matas secundárias, principalmente à sombra, onde geralmente forma grandes populações. No Rio de Janeiro, ocorre na floresta ombrófila densa de terras baixas, submontana e montana, desde o nível do mar até 700 metros de altitude.

18. Adiantum terminatum Kunze ex Miq., Verslagen Meded. Vier Kl. Kon. Ned. Inst. Wetensch. Letterk. Schoone Kunsten 1842: 187. 1843.

Fig. 3i-m

Plantas terrestres. Caule curto-reptante, $2-3 \mathrm{~mm}$ diâm., revestido por escamas linear-lanceoladas, castanho-claras a castanho-escuras, ápice agudoafilado e sinuoso, margens ciliadas no ápice, $0,8-2 \times$ $0,1-0,5 \mathrm{~mm}$. Frondes eretas; pecíolo $30-50 \mathrm{~cm} \times 1-$ $4 \mathrm{~mm}$, cilíndrico-anguloso, sulcado adaxialmente, 
preto, revestido por escamas lanceoladas, castanho-escuras, ápice agudo, margens inteiras a levemente denticuladas, 1-2 $\times 0,1-0,5 \mathrm{~mm}$; lâmina 2-pinada, 22-30×26-35 cm, membranácea, verdeclara, idioblastos visíveis em ambas as faces; raque cilíndrica, preta, revestida por escamas lanceoladas, base pectinada, ápice agudo, margens denteadas, 0,8-1,8×0,1-0,4 mm; pinas 3-5 pares, pecioluladas, peciólulo com 0,1-0,4 mm compr., cor do peciólulo passando para a base das pínulas; pina apical conforme; pínulas dimidiadas, ápice arredondadoacuminado, base cuneada, margens serreadas, abaxialmente revestidas por longos tricomas septados, castanho-claros a castanho-escuros, 0,4$1 \mathrm{~mm}$ compr., não articuladas, pínulas reduzidas em direção ao ápice da pina, pínula terminal subrômbica; venação livre, nervuras simples ou furcadas. Soros dispostos nos lados basiscópico e acroscópico das pínulas, $0,1-2 \times 0,1-0,5 \mathrm{~mm}, 1-12$ por pínula; indúsio oblongo-linear, membranáceo, com tricomas septados.

Material examinado: Cachoeiras de Macacu, Estrada entre Funchal e Guapiaçu, 2.IV.2009, K. Baber 171 (RB); Resende, 27.IV.1926, Hoehne, s. $n$. (R).

Adiantum terminatum caracteriza-se pela lâmina 2-pinada, pelas pínulas reduzidas em direção ao ápice da pina e pínula terminal sub-rômbica, escamas lanceoladas de base pectinada na raque e pela pínula e indúsio densamente cobertos por tricomas septados.

Ocorre do México à Bolívia e Brasil, onde pode ser encontrada desde os estados da região Norte até Santa Catarina. Cresce tanto no interior de matas maduras quanto em capoeiras, aparentemente indiferente às condições de luminosidade No Rio de Janeiro, habita a floresta ombrófila densa submontana, ca. de 400 metros de altitude.

19. Adiantum tetraphyllum Humb. et Bonpl. ex Willd., Sp. Pl. 5: 441.1810.

Plantas terrestres. Caule longo-reptante, 2-3 mm diâm., revestido por escamas linear-lanceoladas, castanho-claras a castanho-escuras, ápice agudoafilado e sinuoso, margens ciliadas no ápice, $0,8-2 \times$ 0,1-0,5 mm. Frondes eretas; pecíolo 30-50 cm $\times 1-$ $4 \mathrm{~mm}$, cilíndrico-anguloso, sulcado adaxialmente, preto, revestido por tricomas, castanho-claros a avermelhados, 0,9-1,1 $\times 0,1 \mathrm{~mm}$ e por escamas lanceoladas, base pectinada, castanho-escuras, ápice agudo, margens levemente denticuladas, 1-2×0,1$0,5 \mathrm{~mm}$; lâmina 2-pinada, 22-30 × 25-35 cm, membranácea, verde-clara, idioblastos visíveis em ambas as faces; raque cilíndrica, preta, revestida por escamas lanceoladas, base pectinada e escamas filiformes; pinas 3-5 pares, pecioluladas, peciólulo com 0,2-0,3 mm compr., cor do peciólulo passando para base da pínula; pina apical conforme; pínulas dimidiado-deltóides, ápice arredondado-acuminado, base cuneada, margens serreadas a bisserreadas, abaxialmente com escamas filiformes, base pectinada e tricomas articulados, adaxialmente glabras, não articuladas; venação livre, nervuras simples ou furcadas. Soros dispostos principalmente no lado acroscópico das pínulas, $0,1-2 \times 0,1-0,5 \mathrm{~mm}, 1-12$ por pínula; indúsio oblongo-linear, membranáceo, com tricomas.

Material selecionado: Guapimirim, Estação Ecológica do Paraíso, 10.VII.2006, C. Jascone \& C. Campos 670 (HB). Rio de Janeiro, Campo Grande, 13.VII.2005, $C$. Jascone \& A. Valente 470 (RFFP).

Adiantum tetraphyllum distingue-se pela lâmina 2-pinada, pela presença de dois tipos de escamas na raque, escamas lanceoladas com base pectinada e escamas filiformes, pelas pínulas abaxialmente cobertas por escamas lanceoladas de base pectinada e tricomas articulados, e pelo indúsio com tricomas. Pode ser confundida com A. diogoanum Glaziou ex Baker, mas este apresenta pínulas quadrangulares e cor do peciólulo não passando para o tecido laminar.

Adiantum tetraphyllum ocorre do México à Argentina. No Brasil, pode ser encontrada desde os estados da região Norte até Santa Catarina. É uma espécie ciófila ou tolerante à sombra, que pode ser encontrada em florestas secundárias, em terrenos arenosos, em ambientes secos ou úmidos, formando populações densas. No Rio de Janeiro, ocorre na floresta ombrófila densa de terras baixas e submontana, do nível do mar até 200 metros de altitude.

20. Adiantum windischii J. Prado, Kew Bull. 60(1): 119, fig. 2. 2005.

Fig. 3n-p

Plantas terrestres. Caule longo-reptante, 13,5 mm diâm., revestido por escamas linearlanceoladas, ápice agudo-acuminado, margens inteiras a levemente denticuladas, castanho-claras a castanho-escuras, 0,8-3 × 0,2-0,5 mm. Frondes eretas; pecíolo $12-45 \mathrm{~cm} \times 0,8-2,5 \mathrm{~mm}$, cilíndricoanguloso, sulcado adaxialmente, castanho-escuro a preto, revestido por escamas lanceoladas, base pectinada, ápice agudo, margens inteiras a levemente serreadas, $1,5-2 \times 0,1-0,5 \mathrm{~mm}$ e por escamas aracnóides, 0,1-0,5 mm compr., castanho-claras a avermelhadas; lâmina 2-pinada, 17-25 ×12-28 cm, 
cartácea, verde-escura, idioblastos visíveis em ambas as faces; raque cilíndrico-angulosa, sulcada adaxialmente, castanho-escura a preta, revestida por escamas aracnóides e escamas lanceoladas, base pectinada; pinas 1-3 pares, pecioluladas, peciólulo com 0,3-1 mm compr., cor do peciólulo passando para a base da pínula; pina apical conforme; pínulas dimidiadas, ápice arredondadoacuminado, base cuneada, margens serreadas, abaxialmente revestidas por tricomas septados sobre as nervuras, castanho-claros, 0,5-1,5 mm compr., adaxialmente glabras, não articuladas; venação livre, nervuras simples ou furcadas. Soros dispostos em ambos os lados das pínulas, 0,3-2 $\times$ 0,1-0,8 mm, 1-16 por pínula; indúsio oblongo, membranáceo, glabro.

Material examinado: Itaguai, 21.IX.1958, G. Pabst 4558 (HB). Magé, RPPN El Nagual, 21.IV.2006, C. Jascone \& D. Rodrigues 572 (HB). Rio de Janeiro, Campo Grande, 5.II.2003, M. Santos \& A. Valente 1137 (RFFP).

Esta espécie caracteriza-se pela lâmina 2pinada, pela raque com dois tipos de escamas, escamas lanceoladas com base pectinada e escamas aracnóides, e pelas pínulas abaxialmente com tricomas septados. Adiantum latifolium difere desta espécie por ter a face abaxial das pínulas glabra. Uma espécie que pode ser confundida é $A$. glaucescens, mas esta se diferencia por apresentar pecíolo, raque e lâmina glabras. Duas espécies relacionadas a $A$. windschii são $A$. argutum e $A$. incertum Lindm. A. argutum difere por ter pínulas acuminadas, abaxialmente com esparsas e diminutas escamas setiformes sobre as veias. A. incertum difere por ter pínulas abaxialmente com escamas setiformes sobre as veias.

Adiantum windischii ocorre na Bolívia e no Brasil, onde pode ser encontrada desde o Acre até São Paulo. É uma espécie que ocorre isolada ou formando populações densas, em lugares sombreados ou expostos ao sol. No Rio de Janeiro, habita a floresta ombrófila densa de terras baixas e submontana, desde o nível do mar até 200 metros de altitude.

Dentre as 62 espécies de Adiantum citadas para o Brasil, 30\% ocorrem no Rio de Janeiro, mostrando a grande diversidade do gênero no Estado. A maioria das espécies possui ampla distribuição na região neotropical e apenas $30 \%$ é endêmica para o Brasil. As seis espécies endêmicas ocorrem nas regiões sudeste e sul, mas nenhuma foi considerada restrita ao Rio de Janeiro. Podem ser encontradas desde florestas úmidas até restingas, desde o nível do mar até 850 metros de altitude.
Os dados morfológicos obtidos neste trabalho revelaram-se eficazes na caracterização de cada espécie. O tipo de indumento em Adiantum é muito variável e de grande importância na identificação. Alguns táxons apresentam superfície da folha glabra, enquanto outros podem apresentar um ou dois tipos de escamas ou tricomas. Outras características relevantes para a identificação das espécies são o formato das pinas e pínulas, a cor do peciólulo interrompida ou não na base da pínula e o formato e quantidade de soros.

A formação vegetal onde há a maior abundância de Adiantum é a floresta ombrófila densa submontana, que concentra $90 \%$ das espécies. O gênero também está bem representado na floresta ombrófila densa montana, ocorrendo preferencialmente nas menores altitudes desta formação florestal (até ca. 850m). Alguns registros foram feitos para as raras áreas de floresta estacional semidecidual (A. deflectens e $A$. raddianum) e de terras baixas (A. curvatum, $A$. latifolium e A. obliquum), além das formações aluviais (A. abscissum). Algumas espécies são muito comuns e facilmente encontradas, enquanto outras são mais raras, por serem preferenciais de uma formação florestal em particular, respondendo, muitas vezes, a um gradiente altitudinal específico. Como exemplos podem ser citados Adiantum windischii, A. macrophyllum e A. mynsseniae. Há espécies ainda mais restritivas, que foram registradas apenas em uma única localidade. A. curvatum, encontrada no Morro do Coco, em Campos dos Goytacazes, ocorre unicamente na floresta estacional decidual de terras baixas, um dos últimos remanescentes desta formação vegetal ocorrente no Estado. As espécies generalistas são aquelas que possuem um amplo espectro na variação altitudinal, ocorrendo desde o nível do mar até ca. de 850 metros de altitude. Na maioria das vezes, estas mesmas espécies são encontradas em mais de uma formação florestal. Como exemplos podem ser citadas A. abscissum, A. latifolium, A. raddianum, $A$. serratodentatum, dentre outras.

A maioria das exsicatas analisadas foi coletada nas regiões Metropolitana, Sul e Serrana do Estado. As menores incidências de coleta são registradas para as Regiões Norte Fluminense, Região dos Lagos, Noroeste, Centro Norte e Centro Sul.

Algumas regiões reúnem um grande número de registros (coletas) em função da ocorrência de áreas preservadas, com alta diversidade, geralmente associadas a Unidades de Conservação, como a região da Serra dos Órgãos e da Costa Verde sul fluminense, dentre outras. 
Este estudo contribuiu para o enriquecimento quantitativo e qualitativo das coleções de Adiantum dos herbários do Rio de Janeiro. Os resultados obtidos no presente estudo demonstram que os trabalhos taxonômicos são fundamentais para o desenvolvimento de teorias e padrões em biodiversidade, assim como representam fontes primárias de informação para ações conservacionistas.

\section{Agradecimentos}

Aos curadores dos herbários visitados, o apoio e colaboração prestados a este trabalho. Ao CNPq, a bolsa de Mestrado concedida para a primeira autora e as bolsas de produtividade em pesquisa concedida aos co-autores (processos números 309415/2008-0 e302732/2007-1).

\section{Referências}

Baker, J.G. 1870. Cyatheaceae et Polypodiaceae. In: Martius, C. F. P. \& Eichler, A. G. Flora Brasiliensis. Munchen, Wien, Leipzig, 1: 358-382.

Boldrin, A.H.L. \& Prado, J. 2007. Pteridófitas terrestres e rupícolas do forte dos Andradas, Guarujá, São Paulo, Brasil. Boletim Botânico da Universidade de São Paulo 25: 1-69.

Kramer, K.U. 1990. Notes on the higher level classification of the recent ferns. In: Kramer, K.U. \& Green, P.S. (ed.). The families and genera of vascular plants. Vol. 1. Pteridophytes and Gymnosperms. Springer Verlag, Berlin. Pp. 49-52.

Lellinger, D.B. 2002. A modern multilingual glossary for taxonomic Pteridology. Pteridologia 3: 1- 264.

Lellinger, D.B. \& Prado, J. 2001. The group of Adiantum gracile in Brazil and environs. American Fern Journal 91: 1-8.

Mickel, J.T. \& Smith, A.R. 2004. Pteridophytes of Mexico. Memoirs of the New York Botanical Garden 88: 1-1055.

Pichi-Sermolli, R.E.G. 1996. Authors of scientific names in Pteridophyta. Royal Botanical Gardens, Kew, 78p.

Prado, J. 2000. A new species of Adiantum (Pteridaceae) from Bahia, Brazil. Brittonia 52: 210-212.

Prado, J. 2003. New species in Adiantum from Brazil. American Fern Journal 93: 76-80.

Prado, J. 2004. Criptógamos do Parque Estadual das Fontes do Ipiranga, São Paulo, SP. Pteridophyta: 17. Pteridaceae. Hoehnea 31: 39-49.
Prado, J. 2005a. A new species and hybrid in Adiantum (Pteridaceae) from South America. Kew Bulletin 60: 117-121.

Prado, J. 2005b. Pteridaceae. In: Cavalcanti, T.B. \& Ramos, A.E. (ed.). Flora do Distrito Federal, Brasil. Vol. 4. Embrapa Recursos Genéticos e Biotecnologia, Brasília. Pp. 185-215.

Prado, J. 2010. Pteridaceae. In: Lista de espécies da flora do Brasil. Jardim Botânico do Rio de Janeiro. Disponível em <http://floradobrasil.jbrj.gov.br/2010/ FB091805>. Acesso em Out 2010.

Prado, J. \& Palacios-Rios, M. 1998. Taxonomy and distribution of Adiantum trapeziforme and $A$. pentadactylon. American Fern Journal 88: 145-149.

Prado, J.; Rodrigues, C.D.N.; Salatino, A. \& Salatino, M.F.L. 2007. Phylogenetic relationships among Pteridaceae, including Brazilian species, inferred from $\operatorname{rbc} L$ sequences. Taxon 56: 355-368.

Scamman, E. 1960. The maidenhair ferns (Adiantum) of Costa Rica. Contributions from the Gray Herbarium 287: 3-22.

Schuettpelz, E.; Schneider, H.; Huiet, L.; Windham, M.D. \& Pryer, K.M. 2007. A molecular phylogeny of the fern family Pteridaceae: assessing overall relationships and affinities of the previously unsampled genera. Molecular phylogenetic and evolution 44: 1172-1185.

Smith A.R.; Kathleen, M.P.; Schuettpeltz, E.; Korall, P.; Schneider, H. \& Wolf, P.G. 2006. A classification for extant ferns. Taxon 55: 705-731.

Thiers, B. 2010. [continuously updated]. Index Herbariorum: a global directory of public herbaria and associated staff. New York Botanical Garden's Virtual Herbarium. Disponível em <http:// sweetgum.nybg.org/ih/>. Acesso em Out 2010.

Tryon, R.M. 1972. Endemic areas and geographic speciation in tropical American ferns. Biotropica 4: 121-131.

Tryon, R.M. \& Stolze, R.G. 1989. Pteridophyta of Peru I. Fieldiana, Botany, new series 20: 1-145.

Vellozo, J.M.C. 1825-1827. Cryptogamia. In: Florae Fluminensis. Tipographia Nacional, Rio de Janeiro, 11: 443-461.

Veloso, H.P.; Filho, A.L.R.R. \& Lima, J.C.A. 1991. Classificação da vegetação brasileira, adaptada a um sistema universal. Fundação Instituto Brasileiro de Geografia e Estatística, Rio de Janeiro. 124p.

Winter, S.L., Mynssen, C.M. \& Prado, J. 2007. O gênero Adiantum no Arboreto do Jardim Botânico do Rio de Janeiro. Rodriguésia 58: 847-858.

\section{Lista de exsicatas}

Achethe, P. 125 (17); 334 (15); 390 (17); Almeida, C. 263 (6); Amado, E. F. 23 (1); 31 (1); Araújo, D. 5885 (13); 6202 (1); Atala, F. 1 (1); Barcia, J. 45 (15); 578 (15); 584 (15); 693 (15); 694 (15); Batista, H. P. 195 (1); 196 (1); Bernardi, N. 10 (13); Botelho, P. 3 (1); 24 (19); Brade, A. C. 1162 (6); 9970 (1); 10313 (15); 10818 (1); 11150 (20); 18614 (15); 18645 (6); 21427 (14); Braga, H. N. 6 (6); Braga, J. M. A. 54 (1); 84 (15); 197 (10), 279 (1); 381 (1); 874 (2); 3492 (9); 3685 (16); 4091 (1); 4181 (15); 5475 (6); 6191 
(10); Braga, M. \& Conceição, E. 1 (16); Bueno, A. 20 (1); Camara, U. C. s.n. (17); Camenedo, A. 6 (15); Carvalho, W. B. 105 (6); Candole, D. 33 (15); Carauta, J. P. P. 328 (1); 460 (15); 577 (16); 1107 (14); 1382 (17); 2005 (1); 2466 (13); 2557 (16); 2770 (13); 2784 (15); 3339 (15); 4388 (14); 4595 (3); 4599 (3); 5105 (16); 5320 (6); 5439 (3); 5832 (13); 7210 (15); Claussen s.n. (16); Damasceno, R. N. 618 (15); 665 (1); Dionísio 234 (15); 909 (16); 926 (15); 957 (17); Dória, M. V. 1 (9); Duarte, A. P. 5209 (1); 5519 (1); 9931 (3); 10491 (6); Duarte, O. 207 (1); Emygdio, L. 1322 (1); 2851 (15); 2934 (6); Engelmann, R. A. s. n. (15); Felipe, G. M. 3 (10); Fiaschi, P. 1036 (17); Flaster, B. 105 (7); Fromm, E. 1259 (16); Glaziou, A. 437 (1); 439 (15); 488 (13); 1154 (13); 1156 (16); 1753 (6); 2057 (15); 2317 (8); 2318 (13); 2320 (17); 3565 (6); 3566 (8); 8322 (6); Guerra, M. 1357 (14); 1592 (4); Gurgel 53 (14); Henrique, P. 6 (15); Jacques, E. L. 157 (14); Jascone, C. E. 63 (6); 64 (16); 108 (1); 129 (16); 131 (6); 151 (1); 182 (6); 190 (6); 209 (15); 232 (4); 247 (16); 289 (6); 292 (6); 296 (6); 308 (1); 347 (16); 457 (1); 470 (19); 483 (10); 487 (1); 489 (19); 572 (20); 656 (14); 670 (19); 688 (16); 722 (6); 755 (16); 756 (6); 813 (14); 861 (6); 869 (6); 901 (1); 936 (6); Jouvins, P. P. 126 (15); Konno, T. 122 (1); Kreiger s.n. (17); Kuhlmann, J. G. 21 (16); 67 (14); 6536 (6); Lagasa, E. s.n. (18); Landrum, R. 2014 (1); Lanna, J. P. 9 (15); Lehnvaeke s.n. (16); Leite, P. s n (1); Lima, F. C. 22 (6), 84 (6). Lima, S. 176 (13); 420 (3); Lira, C. 181 (6); Lutz, A. 31 (6); 1860 (16); Lutz, B. 1727 (15); 1896 (16); Luz, M. V. 2 (15); Maas, P. J. M. 3244 (15); Magalhães, M. 9803 (17); Marquete, R. 102 (1); 285 (6); 492 (6); 529 (1); 791 (19); 823 (6); 825 (6); 1106 (10); 1224 (14); 1302 (15); 1492 (10); 1558 (1); 1915 (16); 1943 (10); 2103 (1); Martinelli, G. 1578 (15); Martius s.n. (14); Mello-Silva, R. 1828 (14); Muker 208 (7); Mynssen, C. M. 7 (1); 26 (19); 33 (14); 37 (6); 41 (1); 68 (15); 78 (13); 89 (19); 292 (9); 293 (6); 296 (6); 356 (9); 874 (1); Pirani, J. R. 50 (16); 145 (14); Ochioni, G. 752 (6); 7494 (9); 7559 (9); Pabst, G. F. J. 4558 (20); 4652 (16); 5309 (16); 5329 (17); 5399 (1); 5616 (15); 5860 (6); 8767 (7); Palacios-Balegno 2855 (6); Pereira, E. 1333 (12); Pereira, F. 01.128 (11); 22.41 (1); Pietrobom, M. R. 3378 (7); s. n. (15); Pinheiro, F. 354 (7); Pinheiro, L. 1 (6); Pinheiro, M. F. 665 (16); Pinto, L. J. S. 1 (6); Porto, C. 1562 (17); Prado, J. 1005 (5); 1006 (16); Rente, E. C. 398 (15); Rizzini, C. T. 370 (1); Rocha, E. 1631 (11); Rosa, M. 134 (16); Rosenstock s.n. (19); Sampaio, A. J. 780 (5); Santos, M. C. F. 1137 (20); Santos, M. G. 17 (16); 63 (16); 970 (15); 1028 (16); 1060 (1); 1132 (15); 1291 (6); 1295 (16); 1312 (6); 1334 (15); 1357 (14); 1520 (15); 1592 (4); 1642 (3); 1717 (1); 1916 (1); 2073 (6); Schwacke 846 (1); 847 (1); 5079 (3); Spannagel 484 (16); s.n. (6); Sprengel 75 (1); Sousa, P. 80 (10); Souza, P.V. 2 (15); Souza, V. T. 56 (11); 58 (8); Strang., H. E. 56 (15); 901 (12); Sucre, D. 1239 (1); 1576 (1); 1944 (15); 2184 (17); 2373 (13); 2743 (13); 3343 (15); 3616 (6); $4251(17) ; 4446$ (1); 6369 (1); Sylvestre, L. 401 (1); 420 (1); 465 (1); 598 (6); 605 (16); 1243 (6); 1335 (1); 1497 (13); 1704 (15); Valente, A. A. 131 (1); Valente, G. 880 (11); Vianna, M. C. 1324 (15); Voigt, F. D65C1 (13); D65C2 (13); Winter, S. 11 (6); 20 (3); 30 (15); 31 (15); 33 (16); 39 (15); 45 (16); 149 (15); 208 (15); 212 (6); 237 (15); 238 (15); 360 (1); 361 (1); 362 (1); 363 (1); 364 (1); $365(1) ; 366(1) ; 367$ (1); 368 (1); 369 (1); 370 (1); 371 (1); 372 (6); 373 (6); 374 (6); 375 (6); 376 (6); 377 (16); 378 (16); 379 (16); 380 (16); 381 (16); 382 (16); 383 (16); 384 (16); 385 (6); 386 (6); 387 (6); 388 (6); 389 (6); 390 (6); 391 (6); 392 (6); 393 (6); 394 (6); 395 (6); 396 (6); 397 (6); 398 (6); 399 (6); 400 (6); 401 (6); 402 (6); 403 (6); 404 (16); 405 (16); 406 (16); 407 (10); 408 (10); 409 (10); 410 (10); 411 (20); Zumpichiatti, G. 6 (16); 13 (1). 